\title{
HOMMAGE
}

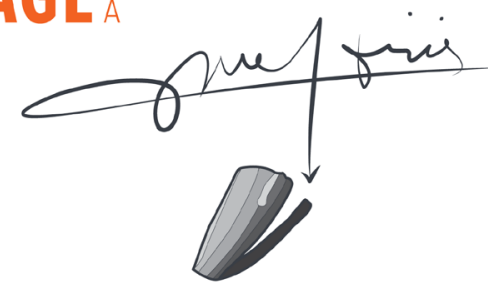

\section{The Use of Bone in Stone Tool Technology: Retouchers from Veternica and Vindija (Croatia)}

\section{Marko Banda ${ }^{1}$, Siniša Radović ${ }^{2}$, Ivor Karavanić ${ }^{3}$}

1 Corresponding author. Department of Archaeology, Faculty of Humanities and Social Sciences, University of Zagreb, Ivana Lučića 3, 10000 Zagreb, email: mabanda@ffzg.hr / markobanda0@gmail.com

2 Institute for Quaternary Palaeontology and Geology, Croatian Academy of Sciences and Arts, Ante Kovačića 5, 10000 Zagreb

3 Department of Archaeology, Faculty of Humanities and Social Sciences, University of Zagreb, Ivana Lučića 3, 10000 Zagreb; Department of Anthropology, University of Wyoming, Laramie, WY 82071

\section{Abstract}

Kivonat

Keywords

Kulcsszavak

Cite as • hivatkozás Banda, M., Radović, S., \& Karavanić, I. (2019-2020). The Use of Bone in Stone Tool Technology: Retouchers from Veternica and Vindija (Croatia). Litikum, 7-8 (Studies commemorating Jacques Tixier), 13-34. https://doi.org/10.23898/ litikuma0023

Article history • Kézirat történet

Copyright • Jogok ๑๑

Bone retouchers are tools used for the tasks of retouching lithics and are usually made from long bone shaft fragments. They are a common feature of many Middle Palaeolithic assemblages throughout Europe and the Near East but are also found during the Late Lower Palaeolithic and the Upper Palaeolithic. This study presents the results of the analysis of bone retouchers from the Middle Palaeolithic contexts of Veternica (MIS 3-5) and the Middle and Upper Palaeolithic contexts of Vindija (MIS 3), Northwestern Croatia. The study is comprised of an examination of site information, taxonomic and anatomical determination, basic taphonomic analysis, morphometric analysis and analysis of the retoucher use traces.

The results reveal a fundamental difference between the two retoucher assemblages. In Veternica, the bone retouchers are an important part of stone tool technology, represented by the number of retouchers, preferential selection of faunal species, preparatory scraping, evidence of curation, the sometimes heavy intensity of use and shaping of the morphology through flaking. In Vindija, retouchers represent a more expedient technology, suggested by the low number of finds in individual layers, their small size, low intensity of use and lack of evidence for preparatory measures and curation. Exceptionally, the assemblage from Veternica has provided retouchers made from cave bear bones, which could suggest exploitation of this species by Neanderthals.

\section{Csonthasználat kőpattintási technológiákban: retusőrök Veternica és Vindija lelőhelyekről (Horvátország)}

A csont retusőrök pattintott kövek retusálására szolgáló eszközök, melyek általában hosszúcsontok töredékeiből készülnek. Jelenlétük általános Európa és a Közel-Kelet középső paleolitikus lelőhelyein, de késő alsó paleolit és felső paleolit példányaik is ismertek. Ebben a tanulmányban az északnyugat-horvátországi Veternica (MIS 3-5) középső paleolit, illetve Vindija középső és felső paleolit (MIS 3) kontextusaiból származó retusőröket vizsgáljuk. A tanulmányban tárgyaljuk a lelőhelyek tulajdonságait, a leletek nyersanyagának rendszertani és anatómiai meghatározását adjuk, illetve alapvetó tafonómiai, morfometriai és használati nyomelemzést mutatunk be.

Az eredmények alapvető különbségeket tárnak fel a két eszközkészlet között. Veternicában a retusőrök a kőpattintási technológia fontos eszközei, amit az eszközök nagy száma, a nyersanyaghoz preferált állatfajok, a karbantartás nyomai, a sok esetben intenzív használat, és a pattintással történő formálás bizonyítanak. Vindijában a retusőrök használat ennél esetlegesebb, amit az ilyen leletek alacsony száma, kis méretük, kismértékű használatuk, illetve az elkészítésükre és karbantartásukra fordított kis figyelem bizonyítanak. A veternicai retusőrök között medvecsont példányok is tatlálhatók, amik arra utalnak, hogy a neandervölgyiek is hasznosították e fajt.

\section{Bone retouchers, Bone tool technology, Middle Palaeolithic, Vindija, Veternica}

csont retusör, csonteszköz technológia, középsố paleolitikum, Vindija, Veternica

Received | Érkezés: 2020. 02. 26. Accepted | Elfogadás: 2020. 03. 01. Published | Közzététel: 2020. 12. 22.

This is an open-access article distributed under the terms of the Creative Commons Attribution License, which permits unrestricted use, distribution, and reproduction in any medium, provided the original author and source are credited. I Ez egy nyílt hozzáférésű publikáció, amit a Creative Commons 4.0 licensze véd. A termék szabadon használható, terjeszthetố és sokszorosítható az eredeti szerző és forrás megjelölése mellett. 


\section{Introduction}

The use of bone tools in the production and maintenance of stone tools is a long-recognized phenomenon. Earliest recognition of such artefacts had already been made in the 19th century, with the first inference of their use in stone technology made by L. Henri-Martin (1906; see Patou-Mathis, Schwab 2002 for a historical perspective). Bone retouchers are artefacts used in the maintenance or shaping of lithic tools. They are commonly made on fragments of long bone diaphyses, but examples on teeth, mandibles, long bone ends with articulations, mammoth tusks and other hard organic materials have been found. The artefacts display linear and deep scores of V-shaped cross-sections, sometimes associated with striations, pits and cortical bone exfoliation (Chase 1990; Mozota 2018). Such traces are occasionally concentrated and/or superimposed into distinct and relatively deep use-areas, but can also appear dispersed and isolated over a larger surface. Even though the anthropic origin of these tools has been previously questioned (Binford 1981), the connection of the traces to the activities of retouching lithics is firmly supported by experimental and taphonomic studies (Armand, Delagnes 1998; Chase 1990; Daujeard et al. 2014; Giacobini, Patou-Mathis 2002; Mallye et al. 2012; Mozota 2013; 2018 and references within) and even by the occasional find of lithic chips imbedded in such artefacts (Abrams et al. 2014; Hutson et al. 2018; van Klofschoten et al. 2015; see Bello et al. 2013 for a study on an experimental piece). However, some documented examples resulting from carnivore gnawing can be misidentified as retouchers (Castel 2004: Photo 4).

The earliest known bone tools used in stone tool production and retouching have been documented in Boxgrove, UK, dated to some 500 ka BP (MIS 13) (Roberts, Parfitt 1999; Smith 2010; Smith 2013). After that, bone retouchers appear from MIS 12 to MIS 9 in several Late Acheulean and post-Acheulean technocomplexes in Europe and the Levant, but are generally poor in number in individual sites (Blasco et al. 2013; Daujeard et al. 2018; Moigne et al. 2016; Rosell et al. 2011; 2015; 2018; Tourloukis et al. 2018), except Schöningen 13II-4 (Hutson et al. 2018; van Klofschoten et al. 2015). It has been suggested that the phenomenon of retouchers occurs in the context of wider behavioural changes (Davidson 2018; Moigne et al. 2016; Rosell et al. 2018; van Klofschoten et al. 2015).

From the end of MIS 9 and the development of the Middle Palaeolithic, bone retouchers become widespread and their frequency increases, at given sites numbering in the hundreds (Auguste 2002; Daujeard et al. 2018; Mozota 2015; Moigne et al. 2016; Rosell et al. 2015; Tourloukis et al. 2018). During this period, retouchers have been found in France (Costamagno et al. 2018; Daujeard et al. 2014; 2018; Mallye et al. 2012; Sévêque, Auguste 2018; Verna, d'Errico 2011), Spain (Barandiarán 1987; Mateo-Lomba et al. 2019; Mozota 2009; 2012; 2015; Pérez et al. 2019), Belgium (Abrams 2018; Abrams et al. 2014; Rougier et al. 2016), Northern Italy (Jéquier et al. 2012; 2018; Leonardi 1979; Thun Hohstein et al. 2018), Germany (Conrad, Bolus 2006; Taute 1965; Toniato et al 2018), Czech Republic (Auguste 2002; Neruda et al. 2011; Neruda, LázničkováGaletová 2018), Slovakia (Neruda, Kaminská 2013); Hungary (Bordes 1968), Slovenia (Turk, Dirjec 1989), Croatia (Ahern et al. 2004; Karavanić, Šokec 2003; Malez 1958; 1981; Patou-Mathis 1997), Montenegro (Morin, Soulier 2017), Greece (ref. in Tourloukis et al. 2018), Crimea (Veselsky 2008), the Russian Altai Mountains (Kolobova et al. 2016) and Syria (Griggo et al. 2011), among others. Middle Palaeolithic retouchers are mostly made from long bone shaft fragments and display no or very marginal shaping of the fragment morphology (PatouMathis, Schwab 2002). Generally, in this period, traces resulting from use are perpendicular or slightly oblique to the long axis of the piece (Abrams 2014). An exceptional feature of the Middle Palaeolithic is retouchers made on Neanderthal bones in Krapina (Patou-Mathis 1997), Les Pradelles (Mussini 2011), La Quina (Verna, d'Errico 2011) and Troisième Caverne of Goyet (Rougier et al. 2016).

Oldest-to-date bone retouchers in East Asia have also recently been recognized at Lingjing in China, in an MIS 5 context comparable to the Eurasian Middle Palaeolithic (Doyon et al. 2018; Doyon et al. 2019). Furthermore, rare finds of bone retouchers are also known from Middle Stone Age contexts in Africa (Campmas 2012; d'Errico, Henshilwood 2007; Henshilwood et al. 2001).

In Eurasia, bone retouchers are also found in Upper Palaeolithic contexts, and sometimes present a change in choice of support (most notably, the use of large carnivore canines) and use with regards to the Middle Palaeolithic (Castel et al. 2003; Conrad, Bolus 2006; Leroy-Prost 2002; Schwab 2002; Soulier 2014; Tartar 2012; Toniato et al. 2018). Certain diachronic differences in retoucher use can also appear between different Upper Palaeolithic industries on the same site (Schwab 2002).

In this paper, we present the results of an analysis of bone retouchers from the Palaeolithic sites of Veternica and Vindija (Croatia) (Fig. 1a). This sample was previously partially published in several works (Ahern et al. 2004; Malez 1958; 1981; Karavanić, Šokec 2003; Karavanić, Patou-Mathis 2009). However, new analytical developments warrant a complete analysis and presentation of the Vindija and Veternica retouchers. Further below we also present pertinent site information, results of lithic and basic zooarchaeological studies to examine in more detail these bone tools. The paper aims to present the finds in a context of recent improvements in the study of such artefacts, to infer possible modes of procurement and use and to evaluate their role in subsistence strategies and technological systems.

\section{Site information}

\subsection{Veternica}

Veternica cave is a large karstic cavity system located northwest from Zagreb, on the mountain of Medvednica, 306 m.a.s.l. (Malez 1965). The site was excavated by Mirko Malez from 1951 to 1955 and again in 1971 (Malez 1981). Archaeological remains are located exclusively in the entrance part of the cave, with an entrance gallery from which a northwestern corridor branches off (Malez 1965). Today, the opening is more than 4 meters high and approximately 8 meters wide. The entrance gallery is some 15 meters long and more than 

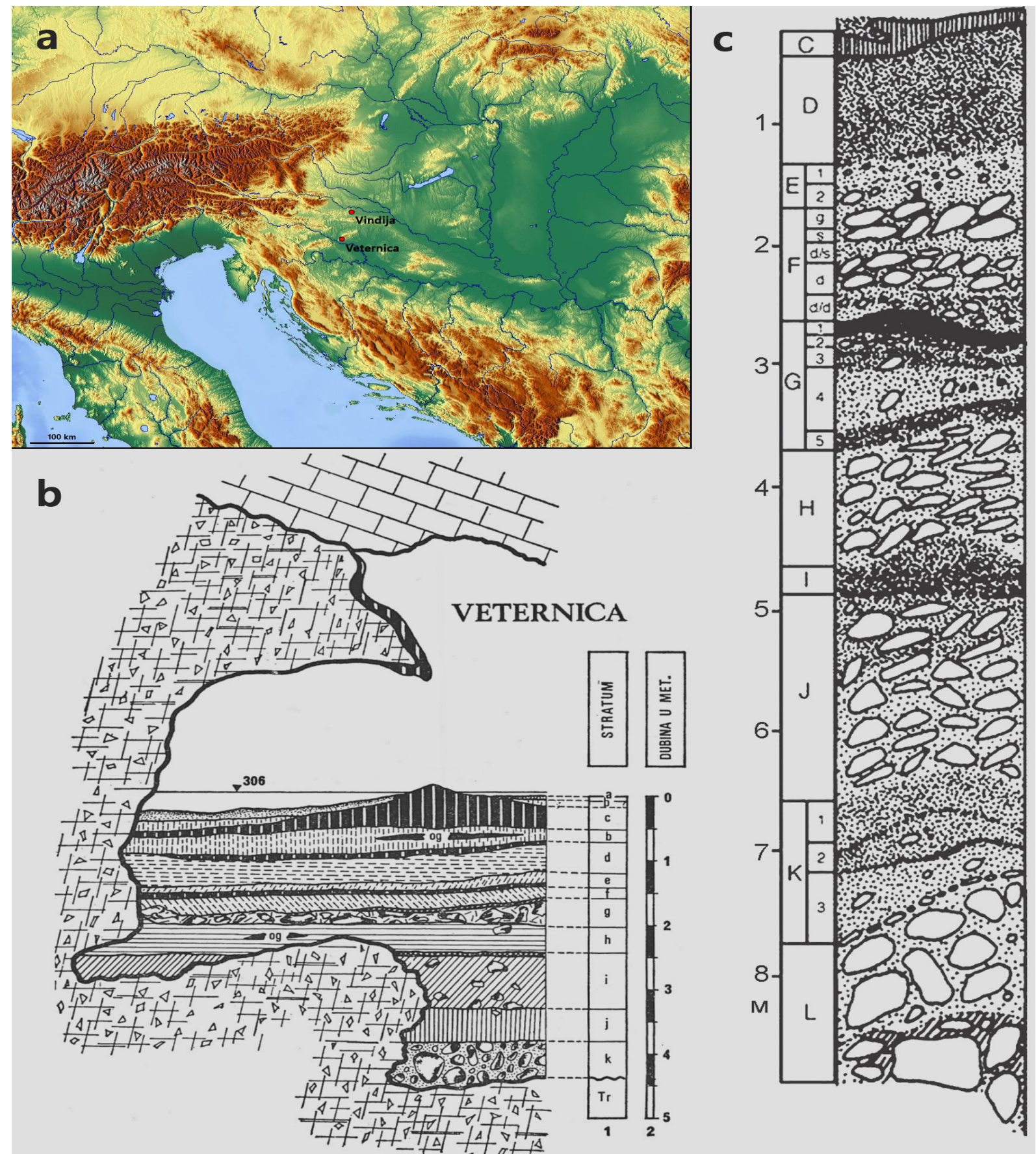

Figure 1. a) Map showing the location of Veternica and Vindija; b) stratigraphic profile of Veternica (after Malez 1981: SI. 1); c) stratigraphic profile of Vindija (after Ahern et al. 2004: Fig. 1) (Edited by M. Banda).

8 meters wide in its widest part, with an average height of 5 meters. The smaller left corridor is 14 meters long, 3 to 7 meters wide and 4.5 to 6 meters tall (Malez 1965). The site has yielded archaeological remains from the Middle Palaeolithic to the Roman period (Malez 1981).

The stratigraphic sequence has revealed the presence of eleven Upper Pleistocene and Holocene geological layers laid atop of Triassic limestone bedrock, marked in alphabetical order from A to K (Fig. 1b) (Malez 1965). Layers J, I and H have yielded Mousterian lithic artefacts, along with faunal remains and traces of hearths. In layers I and $\mathrm{H}$ bone retouchers were also found, reportedly more than twenty pieces (Malez 1981). Layer J is dated to the last interglacial (MIS 5e), while layers I and $\mathrm{H}$ are broadly dated to MIS 5 or MIS 4/MIS 3 (Miracle, Brajković 2010; Miracle et al. 2010). Layer G atop of layer $\mathrm{H}$ is thought to represent a roof collapse or massive slope erosion, which buried the entrance almost completely, probably creating a hiatus in hominin and large mammal occupation of the cave. This event is thought to have occurred either during a colder phase of MIS 3 or during MIS 4 (Malez 1965; Miracle, Brajković 2010).

Among the faunal assemblages of layers $\mathrm{H}-\mathrm{J}$, cave bear (Ursus spelaeus) remains predominate with about $75 \%$, but are less frequent (99\%) than in Upper Pleistocene layers E and F, with rare evidence of hominin activity (Malez 1963; Miracle, Brajković 1992). This implies that the cave was 
interchangeably used by hominins and bears during the formation of layers $\mathrm{H}$, I and J, and later almost exclusively by bears as a den (Banda, Karavanić 2019; Brajković 2005; Miracle 1991). About $82 \%$ of ungulate remains were found in layers $\mathrm{H}-\mathrm{J}$ and $78.6 \%$ of that are remains of red deer (Cervus elaphus). These are followed by bovine remains (about $10 \%$ of all ungulate remains of layers $\mathrm{H}-\mathrm{J}$ ), mostly attributed at the genus level (Bos/Bison), but Bison priscus was more precisely recognized in layers I and J. Roe deer (Capreolus capreolus), elk (Alces alces) and chamois (Rupicapra rupicapra) remains are comparatively rare, about $3 \%$ each of all ungulates of layers H-J (Brajković 2005). The difference between the faunal spectrum of layers $\mathrm{H}-\mathrm{J}$ and E-F suggests that hominins had an active role in the accumulation of cervid and bovine remains, which is supported by a basic taphonomic analysis and the almost exclusive (in the range of 90-95\%) find of these species in layers H-J (Brajković 2005). These layers have also featured remains from Canis lupus, Vulpes vulpes, Mustela erminea, Mustela putorius, Martes martes, Meles meles, Felis silvestris, Panthera spelaea, Panthera pardus and Lepus sp. (Miracle, Brajković 2010). Paleoecological studies indicate that layer J was formed under warm and wet conditions and layers I and $\mathrm{H}$ under temperate conditions with some forest cover and wetlands in the regions, but this could be due to several factors (Miracle, Brajković 2010; Miracle et al. 2010).

The lithic assemblage from the three Mousterian-bearing layers was studied as a whole, in the absence of stratigraphical information for most of the lithic finds (Banda, Karavanić 2019). The inhabitants of Veternica made use of heterogeneous raw-material composition. Quartz is the dominant raw-material, followed by different varieties of chert, black eruptive and other less numerous raw-materials (Banda, Karavanić 2019; Blaser et al. 2002). The vast majority of raw materials were procured in the form of cobbles or pebbles, probably from secondary sources in the vicinity of the cave (Malez 1967). The mode of production is divided according to raw-materials. In raw-material group A (chert, black eruptive and other) centripetal cores predominate, with some irregular cores and one bidirectional core. On the other hand, in raw-material group B (quartz) the dominant method of production it that of cobble-wedge cores, i.e. cobbles flaked circularly around a cortical striking platform. Besides evidence of on-site production of lithic tools, there are pieces representing parts of a brought and curated tool-kit (Banda, Karavanić 2019). The tool composition of the site is dominated by various scrapers, followed by Upper Palaeolithic types, notches and denticulates, while other tool categories are not well represented. The assemblage as a whole is characterized as belonging to a sensu lato Charentian type of the Mousterian (Banda, Karavanić 2019), as defined in the literature that deals with the Middle Palaeolithic of Southeastern and South-Central Europe (Broglio, Kozłowski 1987; Kozłowski 1992; Mihailović 2014).

\subsection{Vindija}

The site of Vindija is a limestone cave located $2 \mathrm{~km}$ west of the village of Donja Voća, $20 \mathrm{~km}$ west of Varaždin. It is located in a narrow gorge, the entrance at 275 m.a.s.l. The cave is 50 meters long, 28 meters wide and higher than $10 \mathrm{~m}$. The thickness of the sediments was about 9 meters and encompassed 20 strata dated from the Riss glaciation (MIS 6) to the Holocene (Fig. 1c) (Malez, Rukavina 1979). Complexes F, G and $\mathrm{K}$ are further subdivided into several sublayers (Malez, Rukavina 1979; Wolpoff et al. 1981). The site was intermittently excavated for thirty years by S. Vuković (1950), who first visited the cave in 1928. From 1974 to 1986 it was excavated by Mirko Malez, and most of the Palaeolithic artefacts, Pleistocene fauna and hominin remains come from these excavations. Neanderthal fossil remains were found in layers G1, G3 and I and ones from anatomically modern humans have been found in layer D and the F complex (Ahern et al. 2004; Cartmill, Smith 2009; Malez et al. 1980; Smith et al. 1985; Wolpoff 1999; Wolpoff et al. 1981).

Faunal assemblages from G3 and G1 are similar. Cave bear (Ursus spelaeus) is the most represented taxa (as in other Pleistocene layers), while among herbivores the Cervidae (Megaloceros giganteus, Alces Alces, Cervus elaphus) are dominant (see Patou-Mathis et al. 2018). Aurochs (Bos primigenius) is present in both layers, while roe deer (Capreolus capreolus) and Merck's rhinoceros (Stephanorhinus kirchbergensis) are present only in G1. Among carnivores, besides the already mentioned cave bears, the cave hyena (Crocuta spelaea) and the fox (Vulpes vulpes) are present only in G3 and the wolf (Canis lupus) and the cave lion (Panthera spelaea) are found in both G1 and G3 (Pathou-Mathis et al. 2018). Cave bear remains constitute $86 \%$ of all large mammal remains in G1 and $97 \%$ in G3. All age groups of this species are present and the most likely factor for their accumulation is hibernation death, due to the absence of cut or percussion marks on their bones and consistency with natural causes of fracture, i.e. sediment pressure and trampling. Other carnivore remains likewise display no traces of anthropic manipulation (Pathou-Mathis et al. 2018). The assemblage of herbivore remains, on the other hand, shows evidence of anthropic exploitation in the form of fresh fractures, cut marks and percussion notches. The near absence of carnivore gnawing on ungulate bones also reinforces the idea that they were mainly accumulated by hominins (Pathou-Mathis et al. 2018). Layer G3 also contains Neanderthal fossil remains with evidence of manipulation, suggesting a possibility of cannibalism (Patou-Mathis et al. 2018). A general overview of ungulate remains from the G complex as a whole shows a similar taxonomic composition and evidence of anthropic traces as mentioned above (Brajković 2005).

Ungulate remains from complex $\mathrm{F}$ are likewise dominated by cervid (Alces alces, Cervus elaphus and Megaloceros giganteus) and bovine remains, mainly Bos/Bison, but some more precisely designated as Bos primigenius and Bison priscus (Brajković 2005). Capra ibex and Rupicapra rupicapra are also present among ungulates. Among carnivores of complex F and the predominant cave bears, Canis lupus, Vulpes vulpes, Panthera spelaea and various Mustelidae are present (Miracle et al. 2010). There is also an assemblage of faunal remains designated as $\mathrm{E} / \mathrm{F}$ but is not presented in more detail in the framework of this study, given that it contains remains from several different layers with different depositional conditions (Miracle et al. 2010). 
Most of the archaeological material from the G complex, in particular layers G1 and G3, has been thoroughly analyzed. The G3 lithic assemblage was mainly produced by a non-Levallois flake technology but has additional evidence of bifacial and blade technology (Karavanić, Smith 1998). The industry is Mousterian, dominated by retouched flakes, notches, denticulates and scrapers, with the addition of some Upper Palaeolithic tools such as endscrapers (Ahern et al. 2004; Karavanić, Smith 1998). The technology of the G1 lithic assemblage is the same as in G3. Furthermore, the lithic tool composition is very similar, with endscrapers on flakes and blades, scrapers, denticulates and a bifacial point (Karavanić, Smith 1998). However, this typological classification has been challenged by Zilhão (2009), as he has recognized that a part of the tool assemblage belongs to pseudo-tools. Another striking feature of layer G1 is the presence of characteristically Aurignacian bone points, both Mladeč and split-base types, and their association with Neanderthal fossil remains. This has led researches to either characterize the G1 assemblage as a transitional culture with possible evidence of acculturation with anatomically modern humans (Karavanić, Smith 1998; Montet-White 1996) or a mixed assemblage due to post-depositional processes (Bruner 2009; Kozłowski 1996; Zilhão 2009; see Karavanić, Smith 2013 for a review of interpretations of G1). The most recent direct radiocarbon AMS dating, based on the extraction of hydroxyproline amino acid, of the G1 Neanderthals suggest they are older than 44 cal. ka BP and thus do not overlap with anatomically modern humans in this part of Europe (Devièse et al. 2017), but confirmation of this requires the dating of early modern human remains from Europe with the same technique.

The layers above the $\mathrm{G}$ complex are thought either to represent a sequence of Aurignacian (Fd/d), unknown (F/d), Gravettian (Fd/s; F/s; E/F) and Epigravettian (D) industries (Karavanić 1995) or Aurignacian (from Fd/d to E/F) and Epigravettian (D) with a major hiatus in between (Zilhão 2009). Karavanić and Smith (2013) have more recently accepted the possibility of the Aurignacian character of layers Fd/d and $\mathrm{F} / \mathrm{d}$, but have cautioned against the Western European subdivision of the Aurignacian in Vindija as proposed by Zilhão (2009).

On the other hand, Middle Palaeolithic assemblages from lower layers (i.e. from G4 onwards) have not been published in detail, except from the perspective of raw-material procurement (Blaser et al. 2002; Kurtanjek, Marci 1990). Generally, the Middle Palaeolithic lithic assemblages are predominantly made on quartz (50-80\%), followed by variable quantities of tuff and chert in different layers. On the other hand, Upper Palaeolithic industries display a more balanced ratio of chert and quartz and even a predominance of chert in the Late Upper Palaeolithic (Blaser et al. 2002). Interestingly, the raw-material composition of the industry in layer G1 is intermediate between the Middle and Upper Palaeolithic industries (Ahern et al. 2004).

\section{Materials and methods}

\subsection{Materials}

The sample in question comprises of 33 bone retouchers from Veternica and 4 from Vindija. The entire sample is stored in the Institute for Quaternary Paleontology and Geology of the Croatian Academy of Sciences and Arts in Zagreb.

During the examination of faunal remains from Veternica, we found more retouchers than the approximately twenty pieces reported by Malez (1981). By his account (Malez 1981), all retouchers from Veternica were found in layers $\mathrm{H}$ and $\mathrm{I}$. All of the pieces we found during our examination had no labels with stratigraphic provenience information, but we assumed that they belong to the mentioned layers (see Banda, Karavanić 2019 for the absence of stratigraphic information in Veternica). Furthermore, two photographs from Malez's publications (Malez 1958, Tabla 1; 1981, Sl. 19) directly associate seven of the retouchers with layers $\mathrm{H}$ and I. In his works, Malez $(1958 ; 1981)$ had interpreted these artefacts as percussion retouchers and anvils.

In most recent studies, three retouchers have been recognized in Vindija, yielding from layers G3 and F/d and complex G in general (Karavanić, Patou-Mathis 2009). Other pieces previously described as retouchers (Ahern et al. 2004; Karavanić, Šokec 2003) have been reinterpreted as not resulting from hominin activity (Karavanić, Patou-Mathis 2009). The retouchers from Vindija are all labelled with the layer from which they come from and the year in which they were found. For this study we have distinguished four pieces as retouchers, coming from layers G/d (probably G4 or G5), F/d and the G complex. Thus, we have excluded from the analysis one piece previously considered to be and included one previously considered not to be a retoucher (Patou-Mathis, Karavanić 2009). Three of the selected retouchers come from Middle Palaeolithic contexts, and the one remaining comes from an Aurignacian context.

Additionally, three ambiguous specimens from Vindija are recognized and presented lower in the text (Fig. 6). All of these pieces were previously considered to be retouchers, some either by Karavanić and Šokec (2003), Karavanić and Patou-Mathis (2009), or both. Although these specimens present surface damage resembling retoucher use traces, it is not possible, beyond a reasonable doubt, to exclude other taphonomic agents possibly responsible for their origin. Thus, they are completely excluded from the analysis.

\subsection{Methods}

Traces on the bone surface were first examined macroscopically and with $\mathrm{a} \times 10$ and $\times 15$ hand lens. When necessary, certain traces were further examined with a stereomicroscope.

If possible, the bone fragments were taxonomically and anatomically determined and indeterminate pieces were classified according to size groups according to Miracle and Pugsley (2006). When it was not possible to distinguish between different species of the same genus, the designation 
"sp." was used. Furthermore, we also used the designation "cf.", when the determination, either taxonomical or anatomical, was not completely secure (Reitz, Wing 1999). The assemblages were further examined for the presence of taphonomic traces (anthropic and non-anthropic) not related to the use of fragments in the modification of lithics. It was done to assess the sequence of events and activities which left their traces on the bone surfaces and to understand the timing of the use of fragments as retouchers. This is related to interpreting how the technology of bone retouchers is positioned in the overall mobility and settlement patterns, subsistence strategies, and likewise, whether the technology is essentially opportunistic or a planned aspect to such artefacts exists. Conventional referential literature for taphonomic classification of surface traces was used (Fernández-Jalvo, Andrews 2016; Lyman 1994). Furthermore, we examined the types of fractures (Villa, Mahieu 1991) as related to bone freshness. Based on the types of fractures present and other selected criteria we classified the bone fragments as either complete (all green fractures, fractures do not interrupt retoucher use-areas), almost complete (a mixture of green and dry fractures, has at least two use-areas on opposite sides which are not interrupted by fractures) and fragmented (a mixture of green and dry fractures with only one use-area, or at least one use-area terminated by a fracture, no matter the type of fracture).

Measurement of bone fragments used as retouchers followed that of Malerba and Giacobini (2002). The largest distance of the piece was measured as its length (L) and designated as the long axis. Width (W) is measured as the widest distance perpendicular to the long axis. Thickness (T) of the cortical bone was measured near the use-area of the piece, usually within $10 \mathrm{~mm}$ from it. Length (Lua) and width (Wua) of the use-areas were also measured, as was the distance of the last trace in a use-area to the nearest apical fracture surface (Dua-e). Pieces which are recorded as fragmented were measured but excluded from the morphometric analysis of supports, as they can introduce a bias. Two pieces were not measured as their morphology has been substantially altered by post-depositional breakage (VTR 6/R) or rodent gnawing (VTR 18/R).

The types of observed traces resulting from the use in the tasks of retouching lithics were classified according to Mallye et al. (2012) and Daujeard et al. (2014).

Scores are linear and more or less deep marks of rectilinear, sinuous, concave and convex shape, and can have smooth or rough internal surfaces. They are made by a sharp lithic edge penetrating the bone surface. They sometimes have internal microstriations which are perpendicular to the overall orientation of the score (Abrams 2018; Malerba, Giacobini 2002) and indicate the direction of the movement which produced them (Daujeard et al. 2014).

- Pits are of triangular or ovoid form, produced by the protrusions on a lithic edge during contact with the bone.

Scaled areas are created when external bone plaques are detached from the bone surfaces. This can result from intense use of the retoucher or if a dry bone or that of intermediate freshness is used.
However, we have not recorded systematically the presence of sliding striations, commonly referred to in other studies (Daujeard et al. 2014; Mozota 2013). This is because such traces can be mistaken for scraping marks or trampling striae, which are both not uncommon in the studied assemblages.

The orientation of bone blanks also followed that of Mallye et al. (2012). In this method, the pieces are always placed on their medullar surface and oriented along the long axis, with the use-area on the distal end (opposite from the observer). If the piece has other use-areas on the opposite end, it is reoriented for the analysis of that use-area.

The location of use-areas was determined as central, apical, lateral or covering (after Mallye et al. 2012). The shape and orientation of the overall use-area with regards to the long axis were classified into one of two categories: subcircular and oval. With that, we also recorded the orientation of the long axis of the oval use-areas in relation to the long axis of the bone blank. Use-areas were also classified according to the pattern formed by individual superposed traces as either hatched (predominantly scores), pitted (predominantly pits) or scaled areas (superficial detachment of bone plaques) (after Mallye et al. 2012). Finally, we classified the use-areas as either lightly (1), moderately (2) or heavily (3) utilized.

Additionally, we also recorded the presence of anthropic scrape marks, as well as their spatial and temporal relation to the retoucher use traces. In the spatial sense, they are either localized/confined to the use-areas, associated (but not confined) with the use-areas or not associated with the use-areas.

No experiments were conducted in the course of this study. Thus, in our comparative efforts, we relied on our earlier experimental results (Karavanić, Šokec 2003) and those of other researchers (e.g. Armand, Delagnes 1998; Daujeard et al. 2014; Mallye et al. 2012; Mateo-Lomba et al. 2019; Mozota 2013).

\section{Results}

\subsection{Veternica}

The retouchers from Veternica are all made from diaphyses fragments of limb bones. Of the 33 retouchers from this site (Tab. 1), 13 are made from ursid bones, seven of which undoubtedly came from cave bear (Ursus spelaeus) remains, two are tentatively attributed to cave bears (Ursus cf. spelaeus), three are attributed to bears on a genus level (Ursus sp.) as well as only one tentative piece (cf. Ursus spelaeus). Retouchers made from bovine (Bos/Bison) bones are present in five specimens. Only two pieces are undoubtedly attributed to red deer (Cervus elaphus), while three more pieces are classified as coming from a large cervid and two other are only recognized on a family level (Cervidae). The remaining pieces have not been determined on a taxon level, and are classified as belonging to a large (6) or medium (2) sized ungulate. The retouchers made from ursid bone are mostly pieces of femurs (11), but there is also one piece from an ulna and one from a humerus. On the contrary, four Cervid bone retouchers (including both Cervus elaphus specimens) are made from 


\begin{tabular}{|c|c|c|c|c|c|c|c|c|c|}
\hline VTR & $\begin{array}{l}\text { Anatomical } \\
\text { element }\end{array}$ & Taxa & Fractures & Length & Width & $\begin{array}{l}\text { L/W } \\
\text { ratio }\end{array}$ & Thickness & $\begin{array}{l}\text { Num } \\
\text { of UA }\end{array}$ & $\begin{array}{l}\text { Scraping } \\
\text { marks }\end{array}$ \\
\hline VTR 1/R & femur & $\begin{array}{l}\text { Ursus cf. } \\
\text { spelaeus }\end{array}$ & Mix & 95.47 & 34.15 & 2.80 & 6.38 & 2 & - \\
\hline VTR 2/R & metacarpus & Bos/Bison & Mix & $80.50^{\star}$ & $39.37^{\star}$ & $2.04^{*}$ & 8.38 & 1 & - \\
\hline VTR 3/R & cf. femur & large ungulate & Mix & $104.32^{*}$ & $58.79 *$ & $1.77^{*}$ & 9.78 & 2 & - \\
\hline VTR 4/R & femur & Ursus spelaeus & Mix & 98.21 & 44.95 & 2.18 & 9.18 & 3 & - \\
\hline VTR 5/R & femur & Ursus sp. & Mix & $103.10^{*}$ & $34.78^{\star}$ & $2.96^{*}$ & 13.03 & 1 & - \\
\hline VTR 6/R & ulna & Ursus sp. & Mix & $\mathrm{n} / \mathrm{a}^{*}$ & $\mathrm{n} / \mathrm{a}^{*}$ & $\mathrm{n} / \mathrm{a}^{*}$ & 9.50 & 1 & - \\
\hline VTR 7/R & femur & Ursus spelaeus & Mix & 119.34 & 41.07 & 2.91 & 9.70 & 2 & - \\
\hline VTR 8/R & radius & Bos/Bison & Mix & 131.76 & 43.52 & 3.03 & 11.46 & 1 & - \\
\hline VTR 9/R & femur & large ungulate & Mix & $78.81^{*}$ & $43.43^{*}$ & $1.81^{*}$ & 7.70 & 2 & - \\
\hline VTR 10/R & metacarpus & Bos/Bison & Green & 88.74 & 40.22 & 2.21 & 7.97 & 1 & + \\
\hline VTR 11/R & humerus & Bos/Bison & Mix & $116.84^{*}$ & $50.89 *$ & $2.30^{*}$ & 4.86 & 1 & - \\
\hline VTR 12/R & femur & Ursus spelaeus & Mix & $88.66^{\star}$ & $33.51^{\star}$ & $2.65^{\star}$ & 6.25 & 1 & + \\
\hline VTR 13/R & cf. femur & large ungulate & Mix & $92.19 *$ & $42.68^{\star}$ & $2.16^{\star}$ & 10.94 & 1 & - \\
\hline VTR 14/R & $\begin{array}{l}\text { indeterminate } \\
\text { long bone }\end{array}$ & large ungulate & Indet. & $92.48^{*}$ & $49.04^{\star}$ & $1.89 *$ & 8.28 & 1 & - \\
\hline VTR 15/R & $\begin{array}{l}\text { indeterminate } \\
\text { long bone }\end{array}$ & large ungulate & Mix & $\mathrm{n} / \mathrm{a}^{*}$ & $\mathrm{n} / \mathrm{a}^{*}$ & $\mathrm{n} / \mathrm{a}^{*}$ & 8.71 & 1 & - \\
\hline VTR 16/R & $\begin{array}{l}\text { indeterminate } \\
\text { long bone }\end{array}$ & $\begin{array}{l}\text { medium } \\
\text { ungulate }\end{array}$ & Mix & 80.74 & 32.38 & 2.49 & 6.64 & 2 & + \\
\hline VTR 17/R & tibia & Cervus elaphus & Green & 75.17 & 23.51 & 3.20 & 5.91 & 1 & + \\
\hline VTR 18/R & femur & Cervidae & Mix & 96.56 & 31.94 & 3.02 & 5.59 & 2 & + \\
\hline VTR 19/R & metatarsus & Bos/Bison & Green & $85.36^{*}$ & $29.56^{\star}$ & $2.89^{*}$ & 7.94 & 2 & - \\
\hline VTR 20/R & humerus & Ursus spelaeus & Green & 88.67 & 53.75 & 1.65 & 10.78 & 1 & + \\
\hline VTR 21/R & radius & large cervid & Mix & $102.86^{\star}$ & $31.04^{\star}$ & $3.31^{*}$ & 8.93 & 1 & + \\
\hline VTR 22/R & $\begin{array}{l}\text { indeterminate } \\
\text { long bone }\end{array}$ & $\begin{array}{l}\text { medium } \\
\text { ungulate }\end{array}$ & Mix & $67.55^{\star}$ & $22.51^{*}$ & $3.00^{*}$ & 8.01 & 2 & + \\
\hline VTR 23/R & femur & $\begin{array}{l}\text { Ursus cf. } \\
\text { spelaeus }\end{array}$ & Mix & 75.83 & 31.45 & 2.41 & 13.22 & 2 & + \\
\hline VTR 24/R & $\begin{array}{l}\text { indeterminate } \\
\text { long bone }\end{array}$ & large ungulate & Mix & $80.62^{*}$ & $30.95^{\star}$ & $2.60^{\star}$ & 10.08 & 1 & - \\
\hline VTR 25/R & femur & Ursus spelaeus & Mix & $103.71^{*}$ & $28.52^{\star}$ & $3.64^{*}$ & 6.68 & 1 & - \\
\hline VTR 26/R & cf. femur & cf. Ursus sp. & Green & 85.37 & 32.83 & 2.60 & 6.61 & 2 & - \\
\hline VTR 27/R & tibia & Cervus elaphus & Mix & $84.50^{*}$ & $29.23^{*}$ & $2.89^{*}$ & 7.05 & 1 & + \\
\hline VTR 28/R & femur & Ursus spelaeus & Green & 110.35 & 33.94 & 3.25 & 7.65 & 2 & + \\
\hline VTR 29/R & tibia & large cervid & Mix & $100.18^{*}$ & $33.10^{\star}$ & $3.03^{*}$ & 5.67 & 2 & + \\
\hline VTR 30/R & tibia & large cervid & Mix & $58.38^{*}$ & $32.65^{\star}$ & $1.79 *$ & 8.65 & 2 & + \\
\hline VTR 31/R & femur & Cervidae & Green & 79.54 & 30.69 & 2.59 & 5.58 & 2 & + \\
\hline VTR 32/R & femur & Ursus sp. & Green & 65.91 & 25.71 & 2.56 & 6.91 & 3 & + \\
\hline VTR 33/R & femur & Ursus spelaeus & Mix & $110.18^{*}$ & $32.09 *$ & $3.43^{*}$ & 7.53 & 1 & - \\
\hline
\end{tabular}

Table 1. Retouchers from Veternica: Anatomical and taxonomical determination; type of fractures; length, width, L/W ratio and thickness of the bone blank; number of use-areas and presence of scraping marks. * - Piece is incomplete and not included in the morphometric analysis.

tibia fragments, two from femurs and one from a radius. Bovine retouchers come from two metacarpal, a metatarsal, a humerus and a radius fragment. The anatomical elements of the ungulate bones classified according to size are mostly indeterminate (5) or come from femurs (3).

Out of the 33 retouchers from Veternica (Tab. 1), 23 present a mix of green and dry fractures. On the other hand, eight pieces have only green fractures and two pieces are indeterminate. The absence of pieces with exclusive dry fractures indicates that all of the bones in the assemblage have been initially broken in a more or less fresh state, either by anthropic or non-anthropic agents. In some cases, the dry fractures are a result of post-depositional damage to the bone and it is evident that such pieces are not complete. On that point, more than half of the assemblage with mixed fractures present green fractures everywhere except on the proximal end of the piece, indicating that some retouchers 


\begin{tabular}{|c|c|c|c|c|c|c|c|c|c|c|c|c|c|c|c|c|c|c|c|c|}
\hline \multirow{2}{*}{ VTR } & \multicolumn{5}{|c|}{ Length } & \multicolumn{5}{|c|}{ Width } & \multicolumn{5}{|c|}{$L / W$} & \multicolumn{5}{|c|}{ Thickness } \\
\hline & $\mathbf{N}$ & Min & Max & Mean & S.D. & $\mathbf{N}$ & Min & $\operatorname{Max}$ & Mean & S.D. & $\mathbf{N}$ & Min & Max & Mean & S.D. & $\mathbf{N}$ & Min & $\operatorname{Max}$ & Mean & S.D. \\
\hline & 14 & 65.91 & 131.76 & 92.26 & 18.21 & 14 & 23.51 & 53.75 & 35.72 & 8.10 & 14 & 1.65 & 3.25 & 2.64 & 0.44 & 33 & 4.86 & 13.22 & 8.23 & 2.09 \\
\hline
\end{tabular}

Table 2. Morphometric results of the Veternica retouchers.

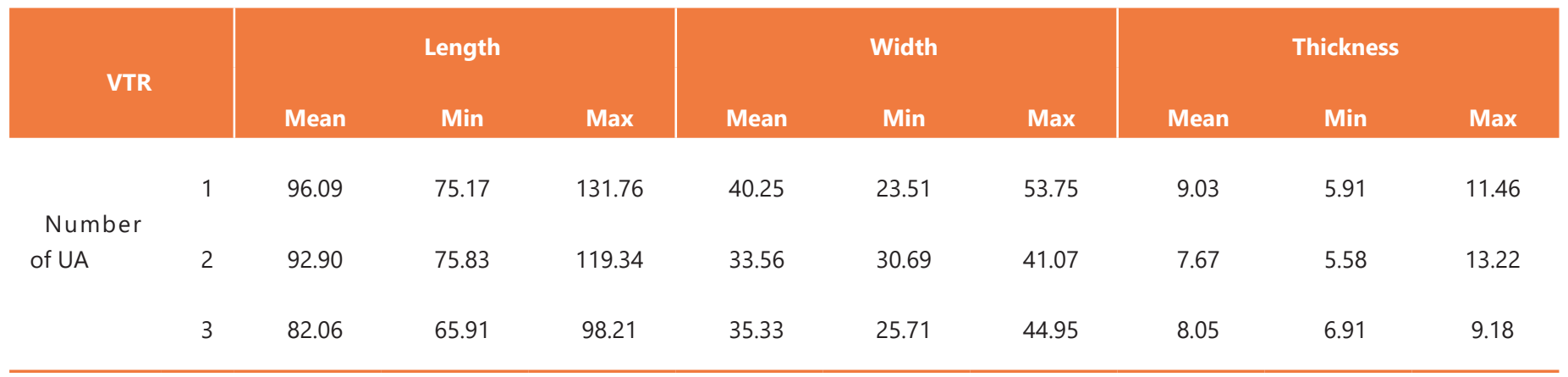

Table 3. Morphometric results of the Veternica retouchers with different numbers of use-areas.

\begin{tabular}{|c|c|c|c|c|c|c|c|c|c|c|c|c|}
\hline \multirow{2}{*}{$\begin{array}{l}\text { Veternica } \\
N=43\end{array}$} & \multicolumn{4}{|c|}{ Length UA } & \multicolumn{4}{|c|}{ Width UA } & \multicolumn{4}{|c|}{ Distance to edge } \\
\hline & Min & Max & Mean & S.D. & Min & $\operatorname{Max}$ & Mean & S.D. & Min & $\operatorname{Max}$ & Mean & S.D. \\
\hline & 9.26 & 43.89 & 21.87 & 8.53 & 5.56 & 26.17 & 14.34 & 4.73 & 0.00 & 23.12 & 6.79 & 4.58 \\
\hline
\end{tabular}

Table 4. Morphometric results of the retoucher use-areas (UA) from Veternica.

were originally longer. However, the presence of only green fractures is not necessarily an indication that a retoucher is complete, which is exemplified by two (VTR 19/R, VTR 31/R) pieces on which green fractures terminate a use-area.

Only 14 retouchers from Veternica were recorded as complete or almost complete and selected for further morphometric analysis (Tab. 1). Mean values are presented in Tab 2. The length of the selected pieces ranges from $131.8 \mathrm{~mm}$ to 65.9 $\mathrm{mm}$, with a mean of $92.3 \mathrm{~mm}$. Width of the pieces ranges from $53.8 \mathrm{~mm}$ to $23.5 \mathrm{~mm}$, with a mean of $35.7 \mathrm{~mm}$. Thus, the ratio of length and width ranges from 3.25 to 1.65 , with a mean of 2.6. The thickness of the pieces near the use-area was calculated on both the complete and incomplete pieces and ranges from $13.2 \mathrm{~mm}$ to $4.86 \mathrm{~mm}$, with a mean of $8.2 \mathrm{~mm}$.

The bones from Veternica generally present a wide variability in the state of surface preservation, owing to different conditions in the cave and complex post-depositional processes. During taphonomic analysis, 19 pieces (57\%) were found to have trampling striae. Mineral staining, possibly manganese and iron oxide, was present on 7 pieces (21\%). Only two pieces had traces of carnivore gnawing and only one had traces of rodent gnawing, which completely altered the morphology of the bone blank. Several traces of anthropic origin were present on the bones. Cut marks occur on eight pieces (24\%) and, when discernable, seem to indicate meat removal. Percussion notches aimed at marrow extraction are present on only two pieces. Traces of burning are present on at least two pieces (6\%), both attributed to secondary exposure.

Anthropic scraping marks are present on at least 15 pieces (45.5\%) (Tab. 1). On all of the pieces, the scraping precedes the retoucher use traces, except perhaps one specimen (VTR 17/R) where scrape marks possibly cover the use traces (Fig. 9a). In all cases of scrape mark presence, they are associated with retoucher traces, two-thirds of them being confined to the surface of the use-areas. The scrape marks are usually associated with all of the use-areas on a piece, but there are two specimens (VTR 4/R, VTR 29/R) where some of the use-areas are and some are not associated with scrape marks. Additionally, there are also two examples of shaping a blank morphology on a lateral side of a bone fragment, which is seen as a sequence of continuous flake scars on the medullar side (VTR 13/R; VTR 18/R) (Fig. 2).

In Veternica, 17 retouchers have a single, 14 pieces have a second and two pieces have a third use-area (Tab. 1). The number of use-areas on a single piece is not proportional to the size of the bone blank, as the mean values of length, width and thickness are all smaller for retouchers with more than one use-areas. (Tab. 3) All in all, 51 use-areas have been identified in the Veternica assemblage.

The position of the use-areas is most often (56.9\%) central on the bone blanks (Fig. 4a). This is followed by use-areas positioned on the right (21.6\%) and left lateral (9.8\%) side. Covering, apical and indeterminate (due to the fragmented nature of the blank) positions are very rare. The shape of use-areas is generally oval, followed by subcircular forms (Fig. 4b). The long axis of oval use-areas tends to be oriented more-or-less in parallel with the long axis of the bone fragment.

There is variability in the distribution of traces in individual use-areas (Fig. 4c). Most traces appear concentrated (45.1\%) and concentrated and superimposed (41.2\%). Dispersed distribution appears on only $13.7 \%$ of the use-areas and there are three retouchers with occurrences of isolated traces outside 


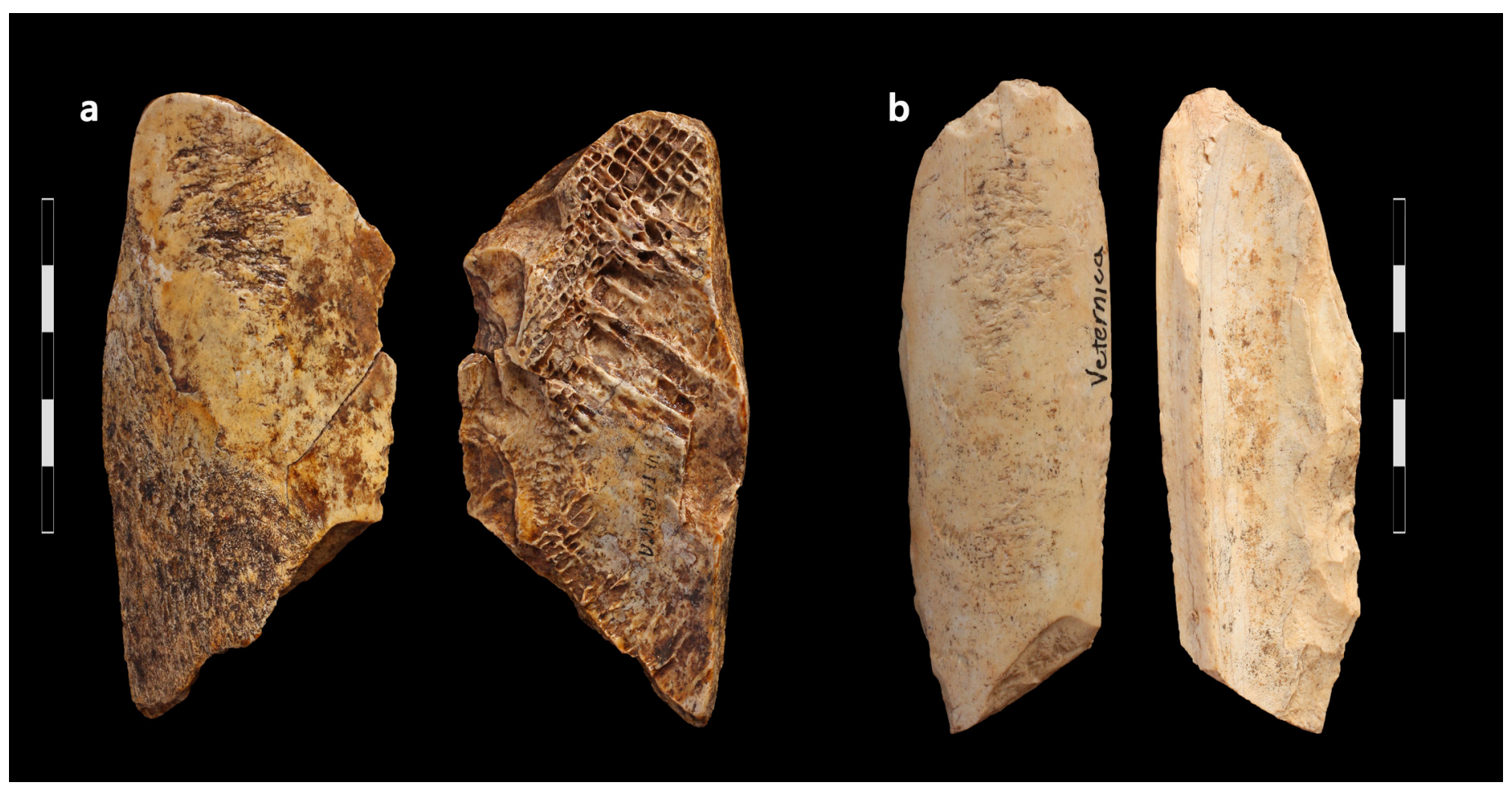

Figure 2. a) Retoucher VTR 13/R (large ungulate; cf. femur) with a single use-area and continuous flake scars on the medullar side, indicating shaping of the morphology; b) Retoucher VTR 18/R (Cervidae; femur) with two use-areas on opposite sides, scraping marks and continuous flake scars on the medullar side (shaping of the morphology). Scale $=5 \mathrm{~cm}$ (Photographed and edited by M. Banda).

designated use-areas. On pieces that have multiple use-areas, one zone usually displays fewer traces and damage than the rest. The orientation of the traces within the use-areas ranges from perpendicular to oblique in relation to the long axis of the tool (Fig. 4d). However, most use-areas present a continuum of variability in the orientation of traces. There are no pieces with traces oriented parallel to the long axis of the bone fragment.

Morphometric analysis of the use-areas included only 43 specimens (Tab. 4), the rest being excluded due to their fragmentation. The mean use-area length is $21.9 \mathrm{~mm}$ and the mean width is $14.3 \mathrm{~mm}$. Distance from the apical edge varies from 23.1 to $0 \mathrm{~mm}$, but in $83 \%$ of cases is located within $10 \mathrm{~mm}$.

In about two thirds (62.7\%) of the use-areas, the traces form a hatched pattern (Fig. 4 e). Scaled surfaces appear on $17.6 \%$ of use-areas and the same percentage belongs to indeterminate patterns due to fragmentation, dispersal or not enough traces to form a discernable pattern. There are no predominantly pitted surfaces, but there is one with a combined hatched and pitted pattern. A depression produced by the intensity of use is present within 12 use-areas (23.5\%). Approximately every third of the studied use-areas is lightly (1), moderately (2) or heavily (3) utilized (Fig. 4f).

The sample displays a wide variability in the number, shape, depth and size of retoucher traces. In the majority of cases, linear scores are much more numerous than pits, although there are 6 specimens (12\%) where the number of pits vs. linear scores is comparable or even greater. The shape of linear scores varies greatly and most use-areas (39\%) have a mix of linear scores with rough and smooth internal surfaces and rectilinear and curved forms. Exclusively smooth or rough linear traces occur respectively on $25 \%$ and $23 \%$ of the useareas. Oval pits occur on $37 \%$ and triangular ones on $14 \%$ of use-areas. A variety of both types of pits occurs on $31 \%$ of all use-areas and $12 \%$ have no traces of pits at all. Scaling is present on $43 \%$ of use-areas and most commonly occurs with heavily utilized use-areas. This heavy utilization, or rather a superposition of traces, generally prevents detailed quantification of the use traces.

A couple of specimens (VTR 3/R, VTR 9/R, VTR 28/R) with a difference in retouch traces in two use-areas on the same apical part of the bone fragment or between two clusters in a single use-area testify that some of the retouchers were used in at least two separate retouching tasks (Fig. 3, Fig. 8a). Two of these specimens, VTR 3/R and VTR 9/R (Fig. 3), may even indicate a utilization in two different states of bone freshness, based on the difference of depth of traces, their surface features and presence the of scaled areas (Mozota 2015; Pérez et al. 2019; Rosell et al. 2011).

\subsection{Vindija}

The Vindija retouchers (Tab. 5, Fig. 5) are also made exclusively from diaphyses of long bones. Vi $75 \mathrm{Ga}$ (Fig. 5a) is made from a metacarpal of a Cervidae, Vi 78 G (Fig. 5b) from a metatarsus of a large cervid, while Vi 79 G/d (Fig. 5d) probably comes from a tibia of a large cervid. The only retoucher from an Upper Palaeolithic level, Vi 78 F/d (Fig. 5c), is made from a tibia of a large-sized ungulate. 


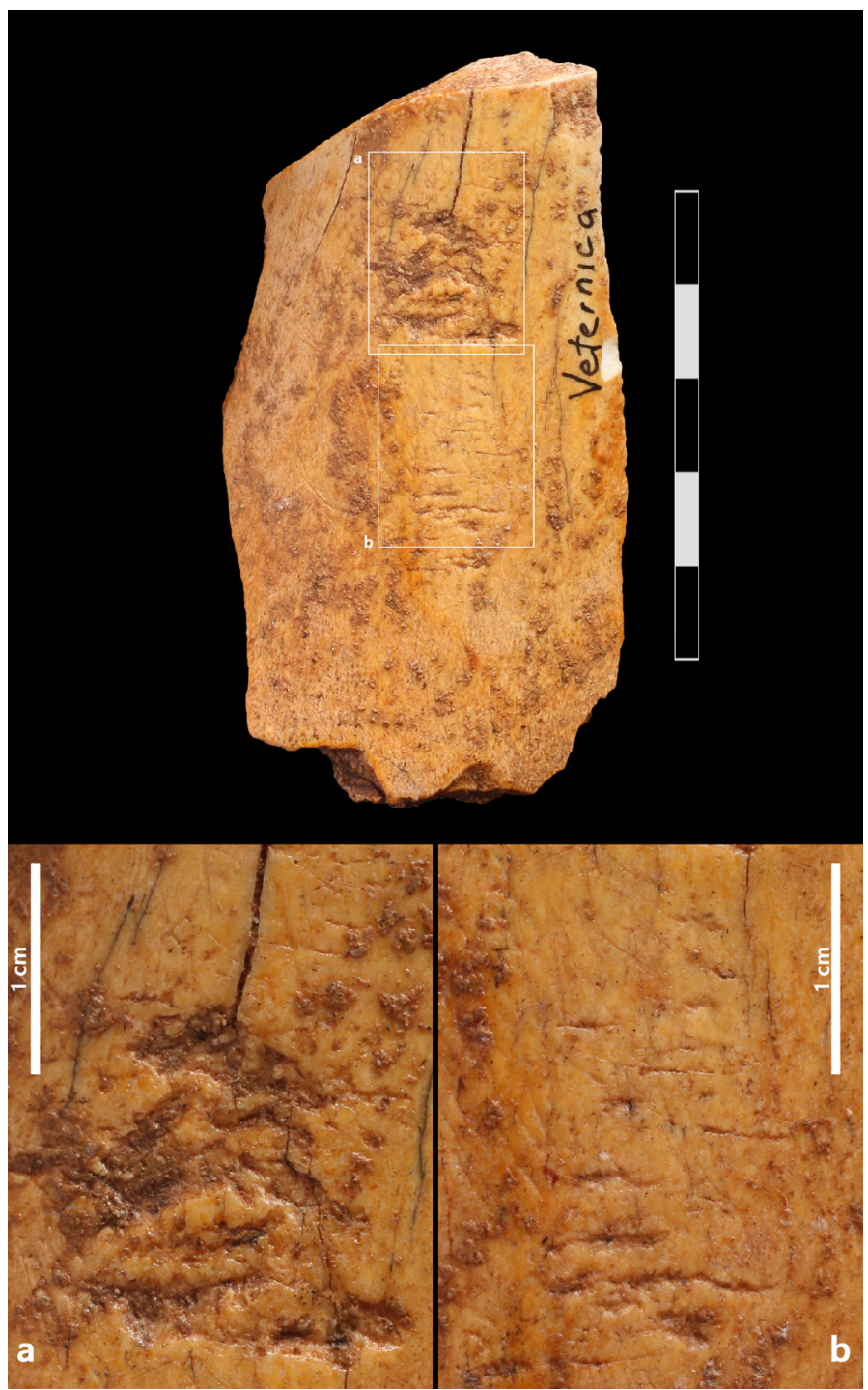

Figure 3. Retoucher VTR 9/R (large ungulate; femur) with two use-areas ( $a$ and $b)$ on the same apical side of the bone blank (proximal side is fragmented). The qualitative difference in the traces could point to use in a fresh (b) and dry (a) state. Scale = $5 \mathrm{~cm}$ (Photographed and edited by M. Banda).

Of the four retouchers (Tab. 5), three present a mix of dry and green fractures and one displays only green fractures. When present, dry fractures almost exclusively occur on proximal and distal edges of the bone fragments, indicating that post-depositional damage to the bone fragments primarily influenced their length. Because all of the pieces have at least partially green fractures, it is safe to assume that all of the bones were initially broken in a fresh state.

According to the presence and position of the dry fractures and locations of the use-areas, one specimen is considered as fragmented and the remainder as complete or almost complete (Tab. 5). The mean length of the complete retouchers is $73 \mathrm{~mm}$ (minimum 72.4 and maximum 74) and mean width is $28.7 \mathrm{~mm}$ (minimum 26.3 and maximum 31.3), the length/width ratio ranges from 2.3 to 2.8 , with a mean of 2.6. If the length and width values of the fragmented pieces are included in the morphometric analysis, the means do not change significantly. The thickness of the bone fragments near the use-areas was calculated on both the complete and fragmented pieces and ranges from 7.3 to $9.1 \mathrm{~mm}$, with a mean of $8.5 \mathrm{~mm}$.
The number and characteristic of taphonomic traces on different bone fragments are variable. Trampling traces occur on two specimens, post-depositional exfoliation (which had terminated a use-area) is present on one piece and there is some indeterminate damage to the bone surface of two specimens that may be due to carnivore gnawing. On the other hand, traces of anthropic origin, i.e. cut marks, percussion notches and evidence of heat exposure are not present, except for scraping marks.

Anthropic scraping traces are present on at least two specimens (Tab. 5; Fig. 5b, c), in both cases associated but not strictly confined to the use-areas of the retoucher as they extend over a significant part of the bone surface. The scraping marks are always terminated by the use-traces, indicating that they occurred before the use of the piece as a retoucher.

Three out of four retouchers have one and a single retoucher has two use-areas (Tab. 5; Fig. 5d). Therefore, five use-areas were recorded. The number of the use-areas on a piece is not dependant on the size of the piece as most pieces have similar dimensions.

The use-areas are mostly in a central position (4/5), followed by one apical position (Fig. 4a). In terms of shape, two use-areas are subcircular and three are oval. The long axis of the oval use-areas is always more or less parallel to the long axis of the bone blank (Fig. 4b).

Use-areas have either concentrated (3/5) or concentrated and superimposed traces (2/5) (Fig. 4c). There are no dispersed or isolated traces. On the piece with two use-areas, one displays fewer traces and damage than the other one. The traces in use-areas are oriented perpendicularly or slightly oblique with regard to the long axis of the piece (Fig. 4d), and even though there is a slight variability of orientation in some use-areas, the traces are generally uniformly oriented.

The morphometric analysis included all five recorded useareas (Tab. 7). The mean length of the use-areas is $15.3 \mathrm{~mm}$ and the mean width is $11.6 \mathrm{~mm}$. Distance from the apical edge varies from 0 to $9.7 \mathrm{~mm}$.

Almost all of the use-areas have a hatched pattern of traces (4/5), except one with a hatched and pitted pattern (Fig. 4e). No depressions resulting from intensity of use have been recorded. Two use-areas are considered to be lightly utilized, another two as moderately and one as heavily utilized (Fig 4f).

Generally, in individual use-areas linear scores are more numerous that pits, but there is one use-area (Vi 79 G/d; Fig. $5 \mathrm{~d}$ - proximal side) where the numerical relation of the two types of traces is comparable. Contrary to that, on one specimen (Vi 78 F/d; Fig. 5c) pits are not recorded. Although of different sizes, linear scores usually appear in two different shapes, either thin and deeper or wide and shallower. In both cases, they have rough internal surfaces. Pits, when present, are always oval. Scaling is present on half of the use-areas but is not predominant and none of the use-areas have a scaled appearance. 


\begin{tabular}{|c|c|c|c|c|c|c|c|c|c|}
\hline Vi & $\begin{array}{l}\text { Anatomical } \\
\text { element }\end{array}$ & Taxa & Fractures & Length & Width & $\begin{array}{l}\mathrm{L} / \mathrm{W} \\
\text { ratio }\end{array}$ & Thickness & $\begin{array}{c}\text { Num of } \\
\text { UA }\end{array}$ & $\begin{array}{c}\text { Scraping } \\
\text { marks }\end{array}$ \\
\hline Vi $75 \mathrm{G} \mathrm{a}$ & metacarpal & Cervidae & Mix & $81.3^{*}$ & $21.6^{*}$ & $3.76^{*}$ & 7.3 & 1 & - \\
\hline Vi $78 \mathrm{G}$ & metatarsus & large cervid & Mix & 72.6 & 31.3 & 2.32 & 9.1 & 1 & + \\
\hline Vi 78 F/d & tibia & large sized ungulate & Green & 72.4 & 28.43 & 2.55 & 9.1 & 1 & + \\
\hline Vi 79 G/d & tibia & cf. large cervid & Mix & 74 & 26.3 & 2.81 & 8.6 & 2 & - \\
\hline
\end{tabular}

Table 5. Retouchers from Vindija: Anatomical and taxonomical determination; type of fractures; length, width, L/W ratio and thickness of the bone blank; number of use-areas and presence of scraping marks. * - Piece is incomplete and not included in the morphometric analysis.

\begin{tabular}{|c|c|c|c|c|c|c|c|c|c|c|c|c|c|c|c|c|c|c|c|c|}
\hline \multirow{2}{*}{ Vi } & \multicolumn{5}{|c|}{ Length } & \multicolumn{5}{|c|}{ Width } & \multicolumn{5}{|c|}{$L / W$} & \multicolumn{5}{|c|}{ Thickness } \\
\hline & $\mathbf{N}$ & Min & Max & Mean & S.D. & $\mathbf{N}$ & Min & Max & Mean & S.D. & $\mathbf{N}$ & Min & Max & Mean & S.D. & $\mathbf{N}$ & Min & Max & Mean & S.D. \\
\hline & 3 & 72.40 & 74.00 & 73.00 & 0.87 & 3 & 26.30 & 31.30 & 28.68 & 2.51 & 3 & 2.32 & 2.81 & 2.56 & 0.25 & 4 & 7.30 & 9.10 & 8.54 & 0.74 \\
\hline
\end{tabular}

Table 6. Morphometric results of the Vindija retouchers.

\begin{tabular}{|c|c|c|c|c|c|c|c|c|c|c|c|c|}
\hline \multirow{2}{*}{$\begin{array}{l}\text { Vindija } \\
N=5\end{array}$} & \multicolumn{4}{|c|}{ Length UA } & \multicolumn{4}{|c|}{ Width UA } & \multicolumn{4}{|c|}{ Distance to edge } \\
\hline & Min & Max & Mean & S.D. & Min & Max & Mean & S.D. & Min & Max & Mean & S.D. \\
\hline & 9.91 & 18.90 & 15.32 & 3.54 & 8.60 & 15.80 & 11.63 & 2.99 & 0.00 & 9.70 & 5.86 & 3.61 \\
\hline
\end{tabular}

Table 7. Morphometric results of the use-areas (UA) from Vindija.

As already mentioned, another three specimens from Vindija are ambiguous, even though their surface damage resembles retoucher use traces. Specimen Vi 75 G b (Fig. 6a) presents a cluster of surface damage on its distal end resembling retoucher use traces, but because of the colour difference (patina) of these traces and the cortical surface of the bone, combined with the presence of other types of damage (trampling striae and cortical bone detachment), it is not possible to the rule out the post-depositional origin of these traces. The variable and dispersed damage on specimen Vi 80 G3 (Fig. 6b), extending from the center to the apical part of the bone fragment, could also be due to carnivore gnawing. Finally, for specimen Vi 78 G3 IIP (Fig. 6c) it is not possible to distinguish if the clustered, shallow and uniformly oriented traces in the central-distal part of the fragment resulted from trampling or use as a retoucher. Given these uncertainties, the pieces are excluded from the analysis, but even in the event of their inclusion the results would not be significantly altered, as they are morphometrically and qualitatively similar to the unambiguously determined retouchers from Vindija, except Vi 80 G3 concerning the characteristics of the possible use traces.

\section{Discussion}

In various sites, the basic selection of blanks according to morphometric criteria is suggested by the larger average dimensions, especially length, of retoucher blanks than of unutilized bone fragments (Costamagno et al. 2018, Jéquier et al., 2012; Mallye et al. 2012; Rosell et al. 2015; 2018; Veselsky 2008). This, however, is not a rule, as sites with comparable dimensions of utilized and unutilized fragments have been documented (Armand, Delagnes 1998; Daujeard et al. 2014;
Auguste 2002). Furthermore, Mozota (2009) has suggested that less heterogeneity in morphometric values of retouchers when compared to non-utilized bones also indicates a selection of blanks used for retouching. As of now, we cannot infer anything about the existence or non-existence of such a selection in the Vindija and Veternica retouchers, primarily because detailed morphometric data of non-utilized bone fragments have not been published. Although the relatively uniform dimensions of the Vindija retouchers may seem as a compelling argument in favour of selection and standardization, the small assemblage size and the distribution among different layers could indicate that this is fortuitous.

When it comes to the comparison of the morphometric characteristics of the two sites, the assemblage from Veternica presents longer and wider blanks on average, but there is a slight overlap with the Vindija retouchers, without (Fig. 7a) or with (Fig. 7b) the fragmented pieces included. Furthermore, although the Veternica retouchers are larger on average, the length-to-width ratio is very similar to that Vindija. Thus, the retouchers from both sites tend to be longer than wider in relatively consistent mode. The average bone thickness of the two assemblages is almost equal, though it is much more variable in the retouchers from Veternica, reflecting the generally greater morphometrical heterogeneity of that assemblage.

Another aspect in the selection of blanks relates to the taxonomic representation in the retoucher assemblage and the overall representation of species in the assemblage from which they come from. At some sites, the faunal spectrum of blanks used as retouchers more or less mirrors that of the parent assemblage (Armand, Delagnes 1998; Auguste 2002; Daujeard et al. 2014; Jécquier et al. 2012; Moigne et al. 2016; 
a

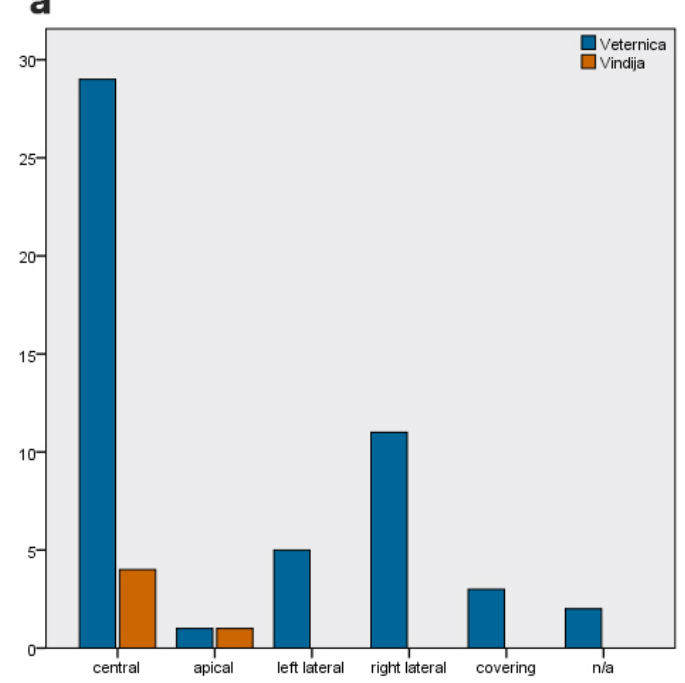

UA Position

C
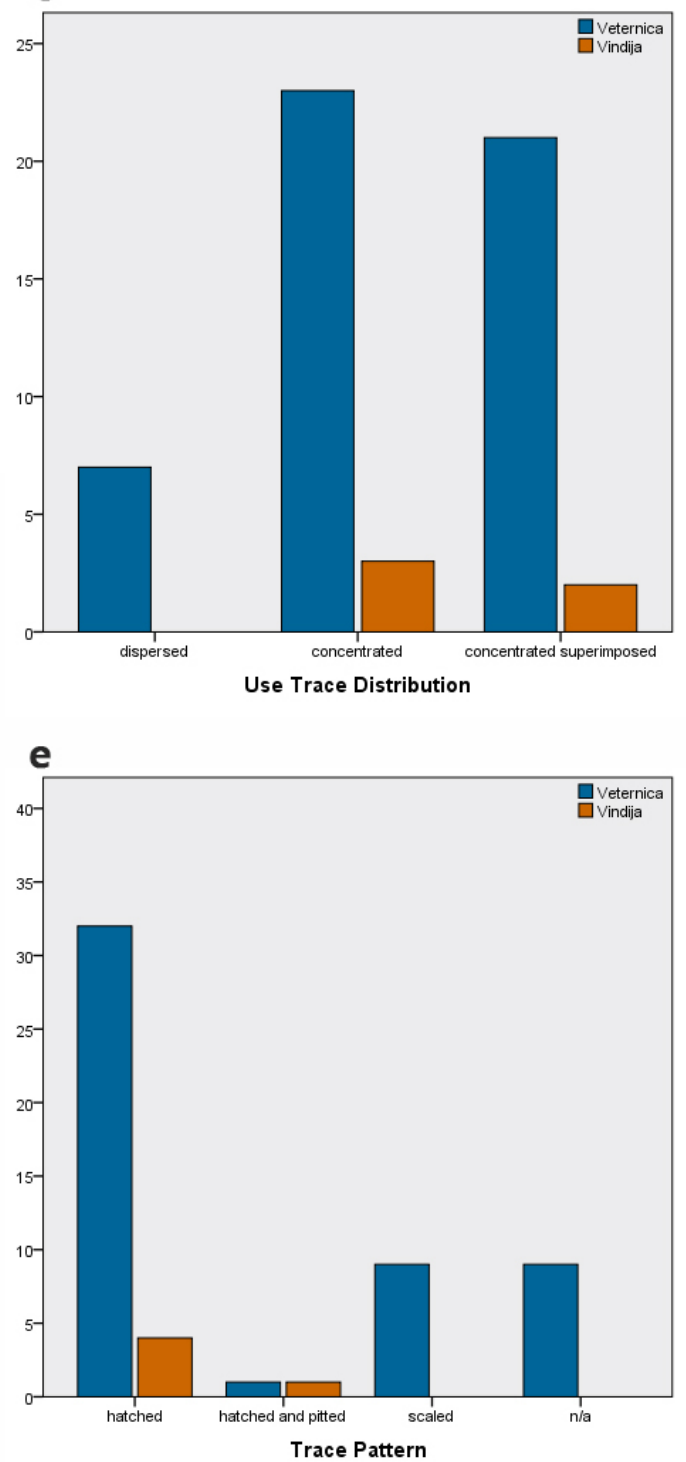

b

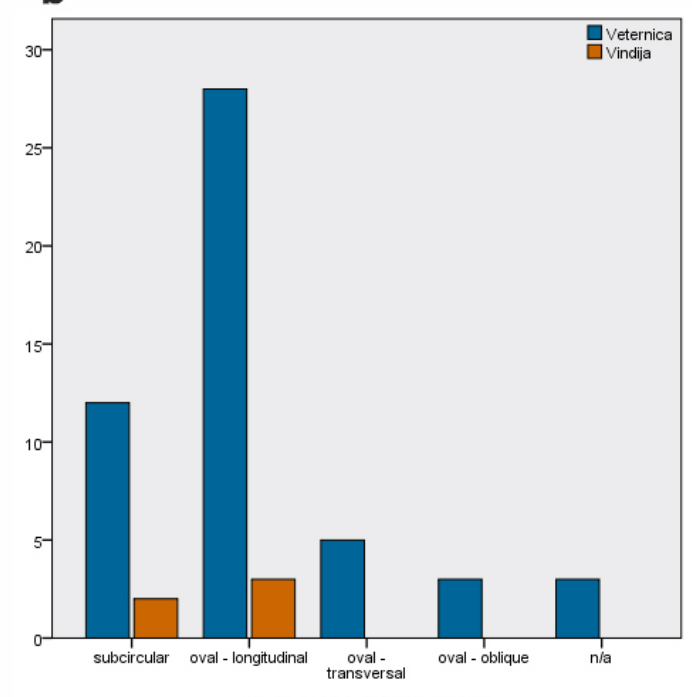

UA Shape \& Orientation

d

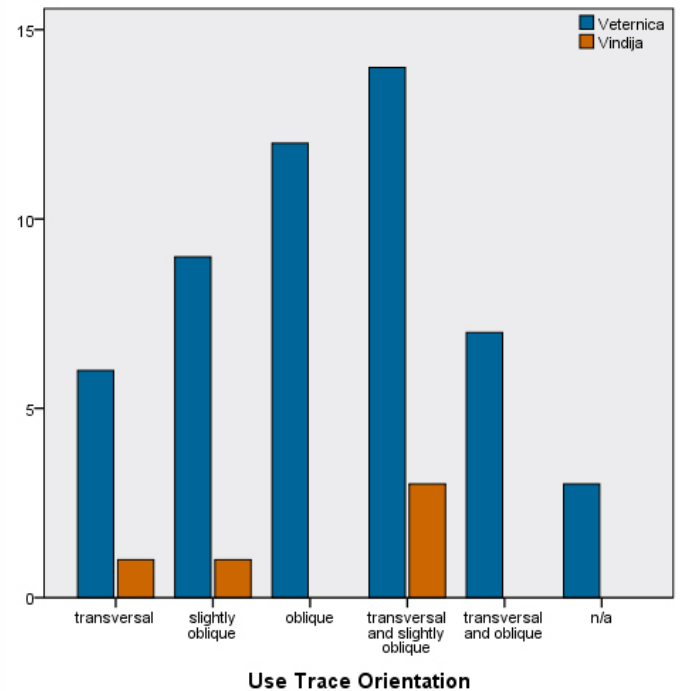

Use Trace Orientation

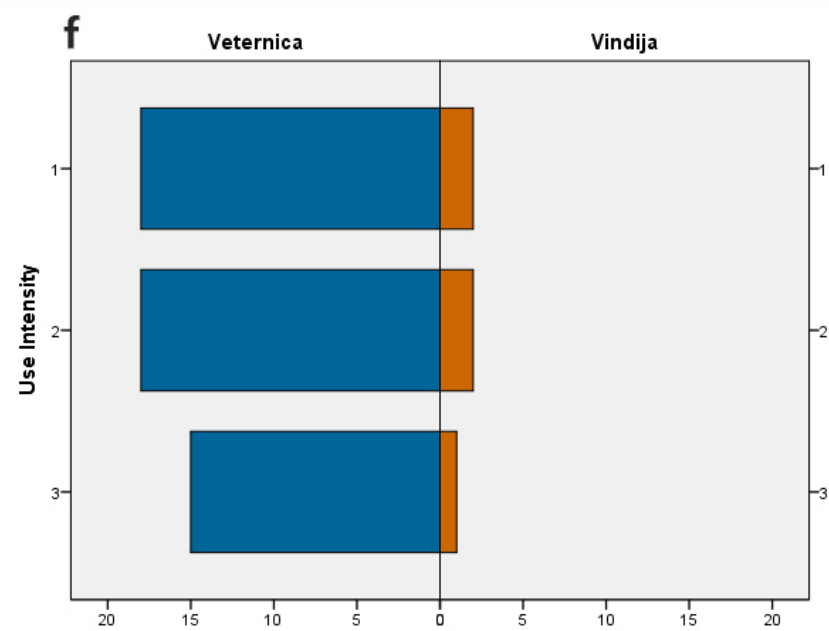

Figure 4. a) Frequency of use-area position classes; b) Frequency of use-area shapes and orientation; c) Frequency of use trace distribution classes; d) Frequency of use traces orientation types; e) Frequency of different patterns formed by use traces; f) Intensity of use (Edited by M. Banda). 
Pérez et al. 2019; van Kolfschoten et al. 2015). On the other hand, some sites present a taxonomic spectrum of retouchers partially or substantially different from the remaining faunal assemblage, which is evident from a clear preference for the utilization of some species which are not as common in the remaining assemblage or the underrepresentation of blanks from species which are common or prevalent in certain assemblages (Mallye et al. 2012; Mozota 2009; Neruda et al. 2011; Rosell et al. 2015). The supposed selection is probably a result of a difference in cortical bone thickness between species and technical requirements of size and robustness for retouchers (Costamagno et al. 2018; Jéquier et al. 2018; Neruda et al. 2011). To Mozota (2009), the selection according to species, along with a lesser morphometrical heterogeneity of retouchers, indicates that there is no random procurement of blanks after the exploitation of the animal carcasses, but that the selection is conducted during the fracture of the bones for marrow procurement.

In Veternica, bear bones are prevalent in the retoucher assemblage, with about $40 \%$. As there are only two remains of brown bear (Ursus arctos) at that site, and both come from layer J (Malez 1963), it is most likely that the bone retouchers determined at the genus level (Ursus sp.) belong to cave bears. Although the cave bear remains, at some 75\%, are dominant in the entire assemblage of layers H, I and J (Malez 1963), most of the cave bear bones are probably the result of natural death during the use of the site as a den (Miracle 1991). Furthermore, bovine remains are rare and, as noted, make only about $10 \%$ of all ungulate remains from layers $\mathrm{H}-\mathrm{J}$, but at least $15 \%$ of retouchers are made from their remains. Even though the red deer is the most common ungulate species in the assemblage and the main species exploited by hominins, only two retouchers are undoubtedly made from its bones. There is a possibility that at most four more retouchers are made from red deer remains (two designated as Cervidae and two as a medium ungulate), but regardless if that were so, red deer remains would still be underrepresented in the retoucher assemblage with regards to the complete faunal assemblage, as they are the main exploited taxa. The three large cervid retouchers may belong to elk (Alces alces), as this is the only recognized large cervid in the entire site, and its remains are found only in layer H. Finally, the remaining retouchers are all made from large ungulate remains. Thus, a clear preference for large-sized mammals is evident in Veternica and we infer that the primary reason for this is cortical bone thickness and robustness as a defining criterion in the selection. The small retoucher assemblage from Vindija relating to each specific layer precludes such an assessment based on the present taxa. However, because most of the retouchers of that site are made from cervid bones, it can be suggested that the faunal spectrum of the retouchers broadly corresponds to the faunal spectrum of the species exploited by hominins.

Neither the Veternica nor the Vindija retouchers display evidence of a complex chaîne opératoire and thus no form of intentional production can be distinguished for these artefacts, as has been proposed for the refitted retouchers from Scladina (Abrams 2018; Abrams et al. 2014) or the retouchers with continuous percussion notches in Peña Miel (Mozota 2015) and Les Abeilles (Soulier 2014). However, VTR 13/R and VTR

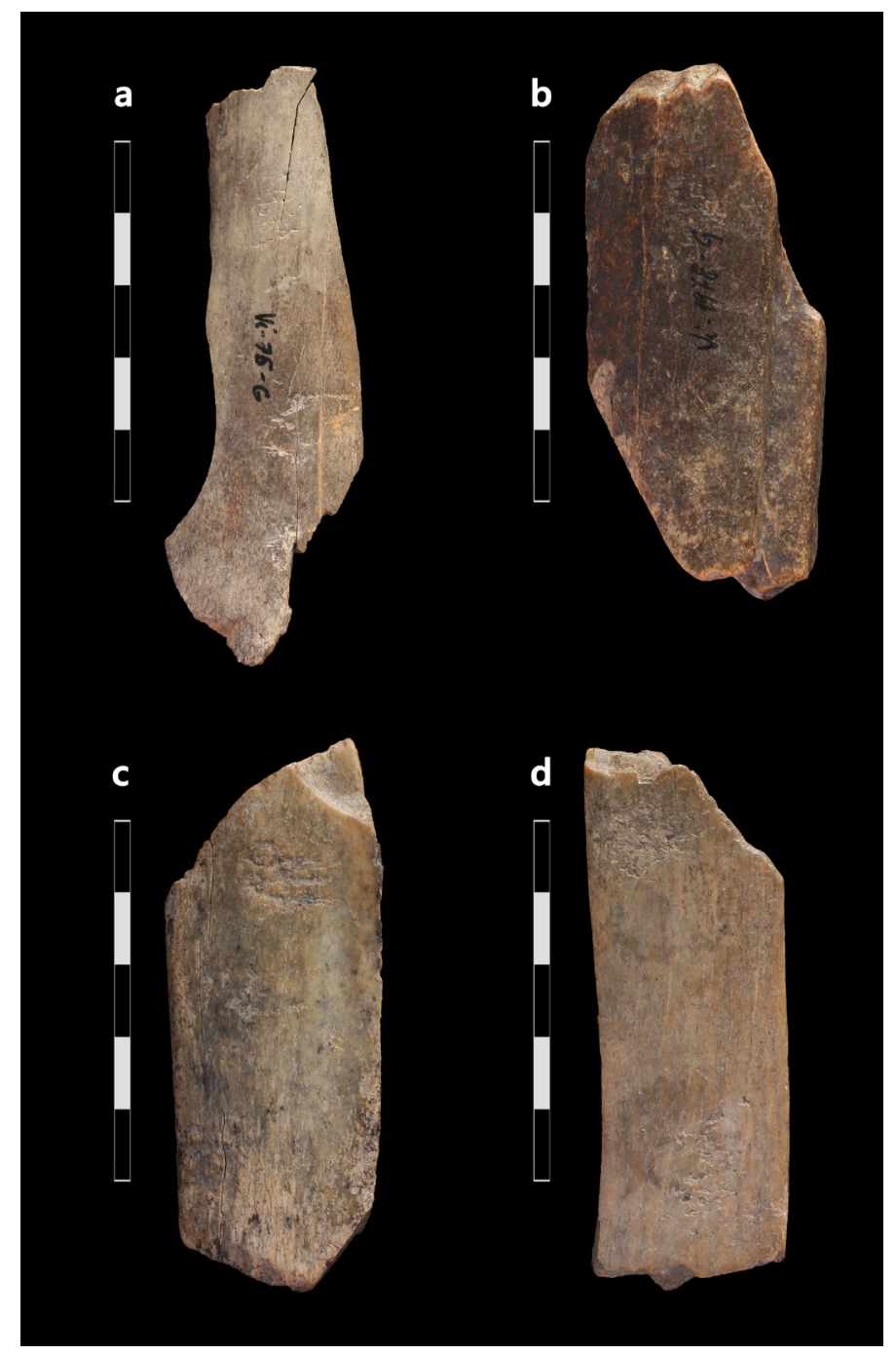

Figure 5. Retouchers from Vindija: a) Vi $75 \mathrm{G} \mathrm{a}$; b) Vi $78 \mathrm{G}$; c) Vi $78 \mathrm{~F} / \mathrm{d}$; d) $\vee 79 \mathrm{G} / \mathrm{d}$. Scale $=5 \mathrm{~cm}$ (Photographed and edited by M. Banda).

18/R from Veternica bear evidence of shaping the bone blank morphology by flaking, a phenomenon also observed at other Lower and Middle Palaeolithic sites (Abrams 2018; Doyon et al. 2018; Rosell et al. 2015).

The use of cave bear bones as retouchers in Veternica opens another topic. Coupled with the use of the cave bear bones as retouchers is the presence of other anthropic marks, mainly scrape and cut marks, and only VTR 7/R has neither of these traces. On two specimens (VTR 20/R and VTR 28/R) scrape marks occur together with cut marks, which in both instances point to meat removal (Fig. 8b). Furthermore, on VTR 28/R, a percussion notch is also present. There is also a virtual absence of carnivore gnawing, as only one piece has tenuous gnawing marks. We hypothesize that all of the stated indirectly implies the exploitation of cave bears by Neanderthals in Veternica, probably as a food and raw-material source. At the Middle Palaeolithic sites of Rio Secco, Grotta di Fumane (Romandini et al. 2018) and Caverna della Fate (Valensi, Psathi 2004) in Italy, Biache-Saint-Vaast (Auguste 2002; Sévêque, Auguste 2018) in France and Scladina in Belgium (Abrams 2018; Abrams et al. 2014) exploitation of bears is associated with the utilization of their bones as retouchers. However, 


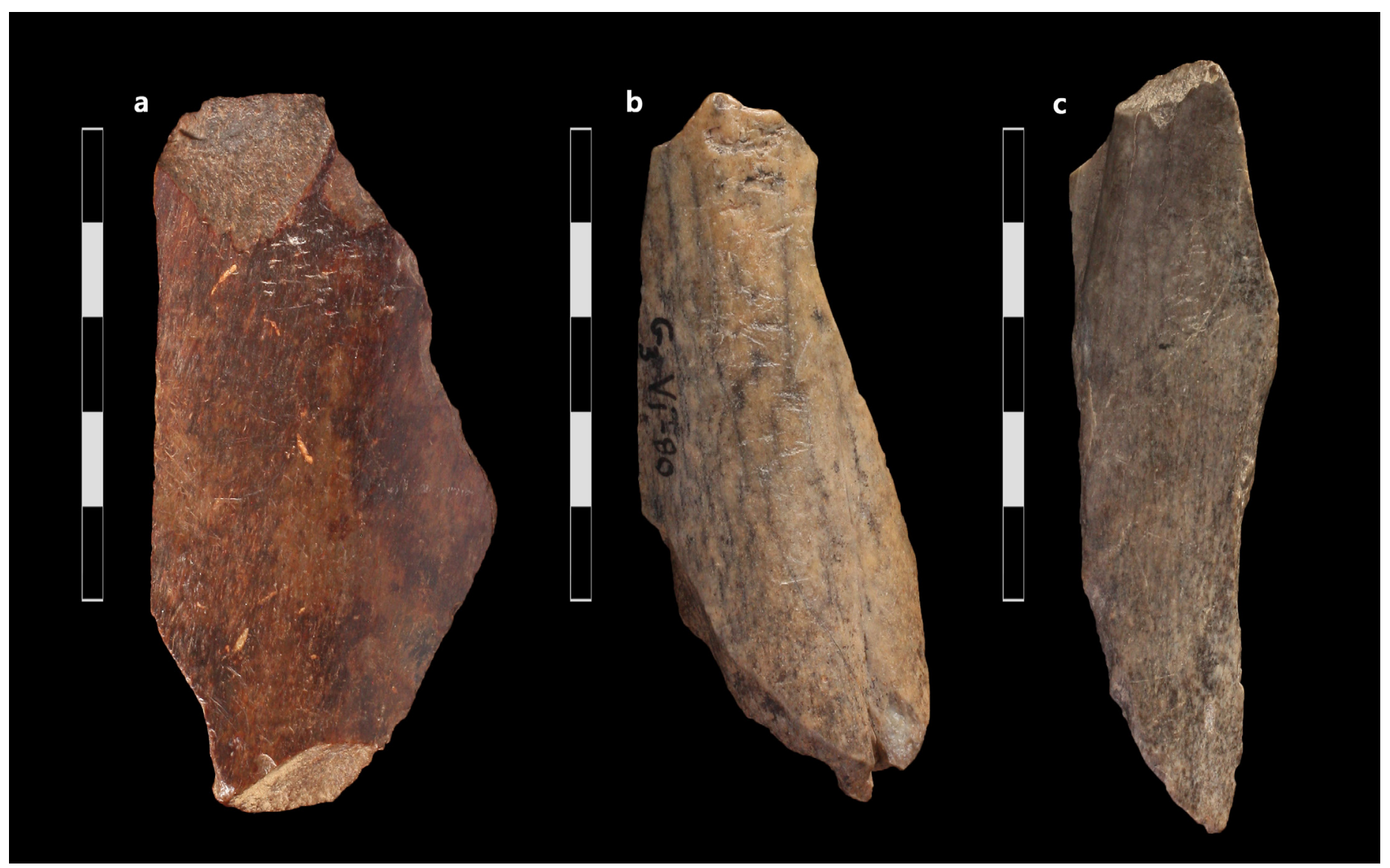

Figure 6. Ambiguous specimens from Vindija: a) Vi 75 G b; b) Vi 80 G3; c) Vi 78 G3 IIP. Scale= 5 cm (Photographed and edited by M. Banda).
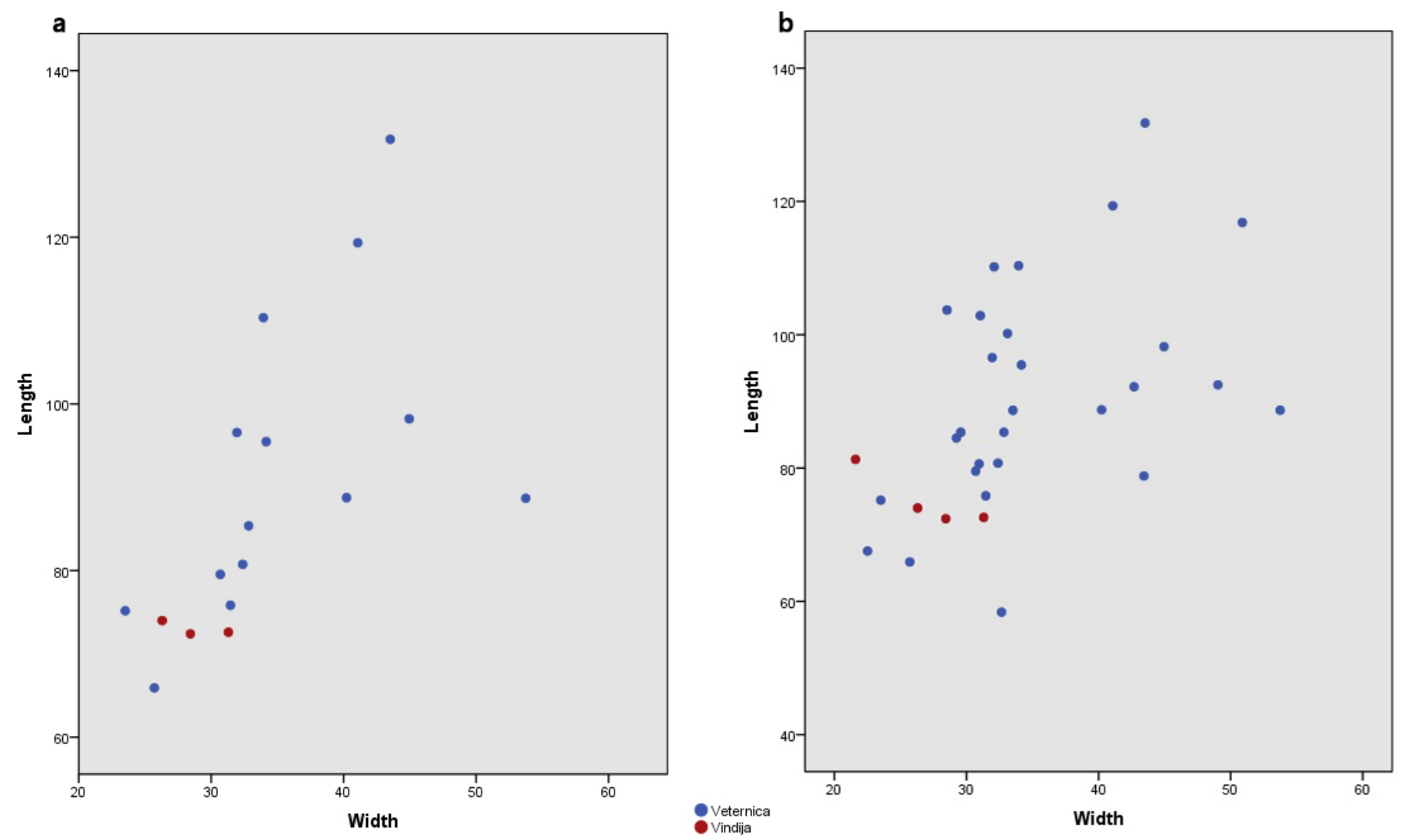

Figure 7. Scatter plot by length and width of the retouchers from both sites without (a) and with (b) the fragmented pieces included. Scale in $\mathrm{mm}$. (Edited by M. Banda). 
only Caverna della Fate (Valensi, Psathi 2004), Rio Secco (Romandini et al. 2018) and Scladina (Abrams 2018; Abrams et al. 2014) have provided retouchers made specifically from cave bear remains.

Whether this indicates the hunting of cave bears or the access to recently deceased bears in the case of Veternica is unresolved and requires further detailed zooarchaeological and taphonomic studies of the entire assemblage of bear remains. The most likely scenario is that it represents opportunistic exploitation of cave bears in their dens, conditioned on a good knowledge of bear hibernation cycles (Romandini et al. 2018). In any case, the use of cave bear remains as retouchers in Veternica is added to the rare Middle Palaeolithic examples and currently represents the largest assemblage of retouchers made from the remains of this taxon.

Scrape marks are commonly found on Palaeolithic bone retouchers and are sometimes confined to the use-areas of the tool. Several authors have suggested that the function of the scraping was to remove the periosteum from the fresh bone to improve the efficiency of the retoucher (Abrams et al. 2014; Armand, Delagnes 1998; Blasco et al. 2013; Daujeard et al. 2014). However, it is also possible that the scraping was intended to renew heavily damaged use-areas (Daujeard et al. 2014; Mozota 2009). Furthermore, Jéquier et al. (2018) have proposed that it may also be a result of the preparation of a lithic edge prior to retouching. Interestingly, out of four retouchers belonging to the same refitted cave bear bone from Scladina, only two have scrape marks (Abrams 2018; Abrams et al. 2014). This indicates that the removal of the periosteum was not an obligatory step prior to the use of fresh bone and that the absence of scraping marks on a piece does not indicate that the bone was used in a dry state (Costamagno et al 2018).

Given that almost half of the retouchers from Veternica have scrape marks and that these scrape marks are usually confined to use-areas and almost always overlain by retoucher use traces, it is most likely that the bones were scraped before their use to remove the periosteum and clean the surface. This is reinforced by the fact that some scrape marks occur with only lightly damaged retoucher use-areas, effectively disqualifying maintenance and repair as an explanation. In Vindija, scraping marks are not exclusively confined to the use-areas but appear over a much larger surface. This may indicate that the scraping was a part of the butchery phase of the exploitation of the carcass and not the preparatory stage for the retouchers (see Mozota 2009). On the other hand, it may simply indicate a different way of preparing a bone blank when compared to the Veternica assemblage, in which the preparation was localized on the surface of the future use-areas.

The presence of localized scrape marks preceding retoucher traces and green fractures which terminate use-areas point to the use of fresh bone fragments as retouchers in Veternica. On the other hand, the use of bones in a dry or intermediate state is also hinted by the possible evidence of recycling (Mozota 2015; Rosell et al. 2011) and by the presence of scaled use-areas (Mallye et al. 2012). However, in the first case, it is not evident that the difference in retoucher traces is the result of reuse of a bone in a dry state, as opposed to reuse in a separate retouching activity with stronger gestures. Furthermore, scaled use-areas can also occur with intensive use or a superposition of traces on a small area (Mozota 2009; 2013; 2018). Thus, neither are clear evidence and the possibility of the utilization of dry bone remains tentative. On the other hand, in Vindija the indication of the state of the freshness of bone blanks during use is even less certain. Green fractures and widespread scraping marks only point that the bones were initially broken while fresh, but do not suggest the timing of the use. It is difficult to clarify if some of the dry fractures present on the pieces occurred before use or after discarding the retoucher. Moreover, even though scaling occurs on some use-areas, it is always small and associated with other more predominant types of use traces. However, even though large-scale scaling and true scaled use-areas do not occur in the sample, their absence is not an indication that the bones were used in a fresh state (Mallye et al. 2012). Therefore, we leave the question of bone freshness during use for Vindija open.

There is an ongoing debate on the duration of use and curation of bone retouchers in the Palaeolithic. Chase (1990) has argued that these are ad hoc tools which have been used in short term retouching activities, mainly for transforming a single lithic edge and then discarded. Others have pointed out that intensive use, either in terms of force or repetition, is required to significantly influence the cortical surface of the bone (Daujeard et al. 2014). Moreover, Armand and Delagnes (1998) have recorded that not all experimental retouchers have macroscopically recognizable use traces. Contrary to that, Mallye et al. (2012) have reported all of the experimental retouchers as having use traces, regardless of their freshness or number of conducted strikes. Recently, Doyon et al. (2018) have classified bone retouchers as either expedient or part of a curated tool-kit, based on the absence or presence of shaping of the artefact morphology, respectively.

The presence of intensively utilized retouchers and multiple use-areas on the same pieces seems to point to the possibility that the retouchers from Veternica are not only expedient tools but that at least some of them were part of a curated tool-kit. Multiple use-areas on a piece point to reuse of a retoucher after the previous use-area became ineffective due to extensive damage (Mozota 2015; Schwab 2002). Furthermore, prolonged use is supported by the presence of several grouped clusters of traces with different characteristics and orientation in the same use-areas, which suggests that the retouchers were used in separate retouching activities. Although there is some indication of recycling the retouchers in a different state of freshness, it is not certain that they were recycled.

The Vindija assemblage, however, seems to represent expedient tools. Most pieces only have a single use-area, with traces which are usually shallow, not numerous and not superimposed. The only exception comes from the lowest layer in the assemblage (Vi $79 \mathrm{G} / \mathrm{d}$; Fig. 5e), but it is not comparable to intensively used pieces from Veternica. The few pieces in 


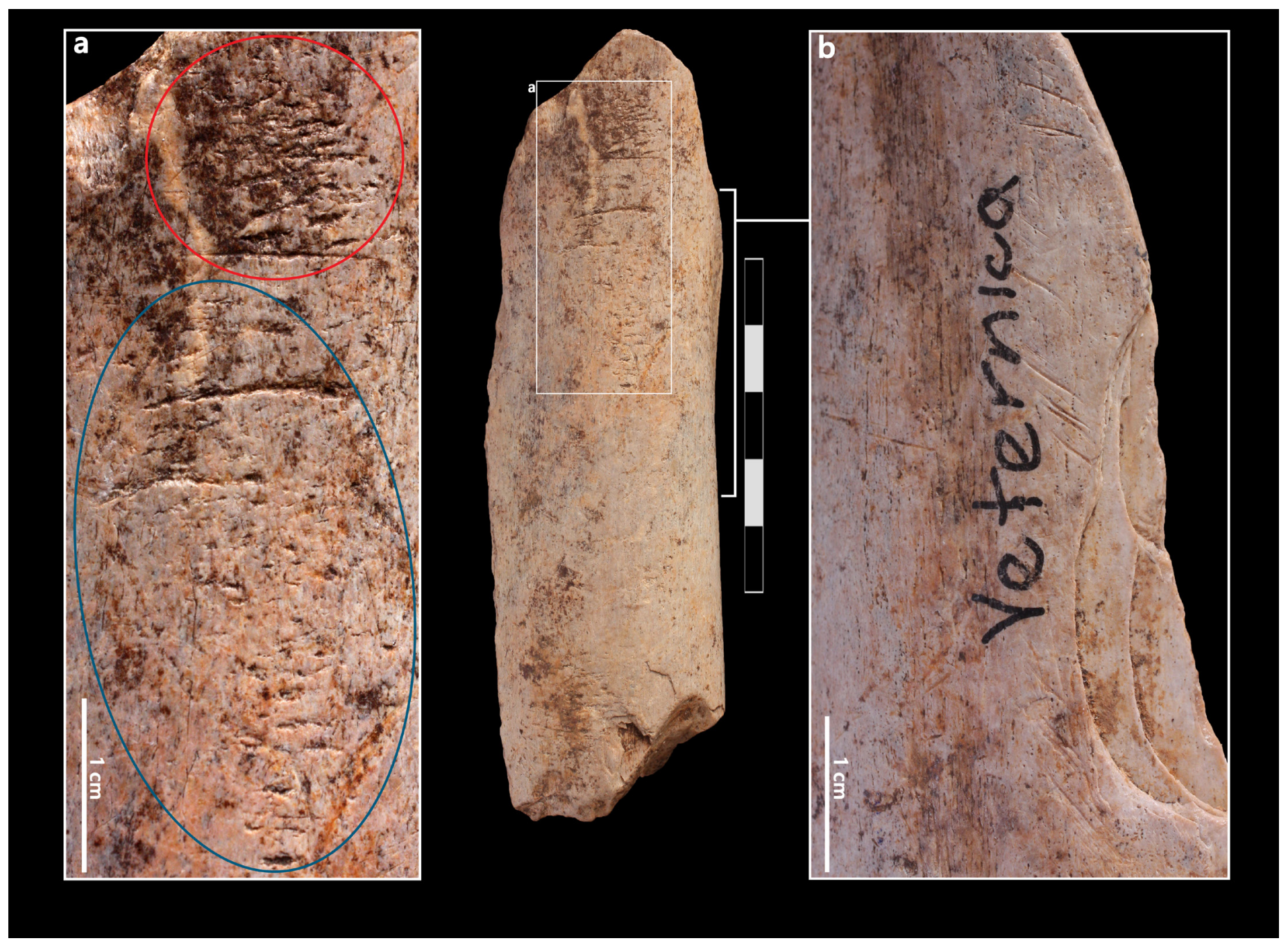

Figure 8. Retoucher VTR 28/R (Ursus spelaeus, femur) with two use-areas on opposite sides. a) A single use-area with two distinct clusters of traces pointing to two separate retouching activities. b) Continuous cut marks indicating meat removal. $\mathrm{Scale}=5 \mathrm{~cm}$ (Photographed and edited by M. Banda).

each specific layer also suggest that these tools do not have a predominant role in the retouching activities of stone tools within those industries.

The question of how the retouchers were used is present since the earliest studies of them. Broadly speaking, they have been considered as percussion, pressure or anvil retouchers (see Patou-Mathis, Schwab 2002 and Mozota 2018 for a historical perspective). Contemporary researchers generally consider them as percussion retouchers, especially when discussing Middle Palaeolithic artefacts (see Mozota 2015). Recent experiments conducted by Mozota (2013; 2018) have focused on the qualitative difference of use traces between pressure and percussion retouchers. His findings have suggested that percussion, when compared to pressure retouching, leaves longer linear scores, less scaling of the use-areas and a higher amount of pits. Furthermore, it was also stated that percussion retouching generally creates oval use-areas that are longitudinal with the long axis of the bone blank and that pressure retouching leaves circular use-areas (Mozota 2015). Doyon et al. (2019) have reported on the presence of pressure retouchers from Lingjing in China, which they distinguish based on the lithic retouch flakes and distinct clustering of the use traces on the retouchers themselves.
When it comes to modes in which retouchers from Northwestern Croatian sites were used, the Veternica assemblage is consistent with the use as percussion retouchers. The use traces in this assemblage usually present variability of orientation, indicating changes in the position of the retoucher and/or lithic edge during the retouching activity, something that is consistent with percussion. Furthermore, the use traces in individual use-areas also display variability with regards to their shape and surface texture. On the other hand, one of us (I.K.) has previously (Karavanić, Šokec 2003), based on experimental results, suggested both active pressure and percussion flaking as the possible modes of use of the Vindija retouchers. Indeed, in this retoucher assemblage, the characteristics of use traces are more homogenous on individual pieces than in Veternica. Likewise, retouchers from Vindija are generally less utilized and in most cases present shallow traces that are concentrated but do not overlap and form depressions. Additionally, while more than half of the use-areas from Veternica are oval and longitudinal with the long axis of the bone blank, the retoucher use-areas from Vindija are divided in half by oval and subcircular shapes. However, we would currently advise caution upon determining pressure retouchers in Vindija. It is possible that a lower reliance on this type of tool in Vindija, i.e. a more expedient character 
of the technology influenced a shorter use period of the pieces and thus the noted differences in the use damage of both sites.

Another question concerns the recognition of lithic rawmaterials retouched by these tools. In comparative experimental studies, retouchers have been used in retouching flint and quartzite (Karavanić, Šokec 2003; Mallye et al. 2012; Mozota 2013; Rosell et al. 2011) and flint and quartz (Mateo-Lomba et al. 2019). Because the dominant raw-materials in both Veternica and Vindija are quartz and flint, we have considered the findings of Mateo-Lomba et al. (2019) as the most pertinent for our study. However, they have not commented on any qualitative difference of the same types of use traces when different raw-materials are retouched but have found that there is a different quantitative representation of various use trace types. Unfortunately, because of the common occurrence of superimposed traces, we have found quantification to be difficult and thus unreliable for our assessment of which raw materials were retouched in Veternica. Also, as lithic tools from Veternica are made from a relatively heterogeneous raw material composition (Banda, Karavanić 2019), we are reluctant to use binary qualities of the use traces to differentiate the raw materials of the retouched tools (e.g. Mallye et al. 2012). This is further motivated by a noticeable overlap of use traces of different characteristics on the same use-areas. The only direct evidence of retouching a certain raw material comes from a possible quartz chip imbedded into a linear mark on VTR 17/R (Fig. 9b), but this must be further confirmed by EDX spectroscopy (see Bello et al. 2013). For Vindija, we can only assume that the retouchers were used on quartz and chert, the most common raw materials at the site (Blaser et al. 2002).

Whether the presence of a single Upper Palaeolithic retoucher from Vindija represents continuity with the Mousterian in this region is currently difficult to confirm. Despite the similarity in dimensions with the Middle Palaeolithic retouchers from the lower layers, there is no unambiguous presence of retouchers in the upper layers of complex G, i.e. layers G2 and G1, the latter of which is the most recent level with $\mathrm{Ne}$ anderthal remains and Mousterian lithics (Karavanić, Smith 2013). Coupled with the conclusion from the most recent dating results (Devièse et al. 2017), the current data leaves open the question of whether the retoucher technology was transferred from Neanderthals to anatomically modern humans in this region or more likely represents a reintroduction by modern humans after the disappearance of Neanderthals.

Finally, the above results point to significant differences between the Veternica and Vindija assemblages. These differences could point to diachronic changes in bone retoucher technology during MIS 4-3 in the regional setting of Northwestern Croatia. Interestingly, it seems this technology is also rare during the Last Interglacial (MIS 5e), as there are no reported retouchers from layer J in Veternica (Malez 1981) and there is only one retoucher from a Neanderthal bone in Krapina (Patou-Mathis 1997) and a couple of ambiguous retouchers from beaver (Meles meles) bones from the same site (Miracle 2007). The differences between Veternica and Vindija probably do not coincide with substantial changes in

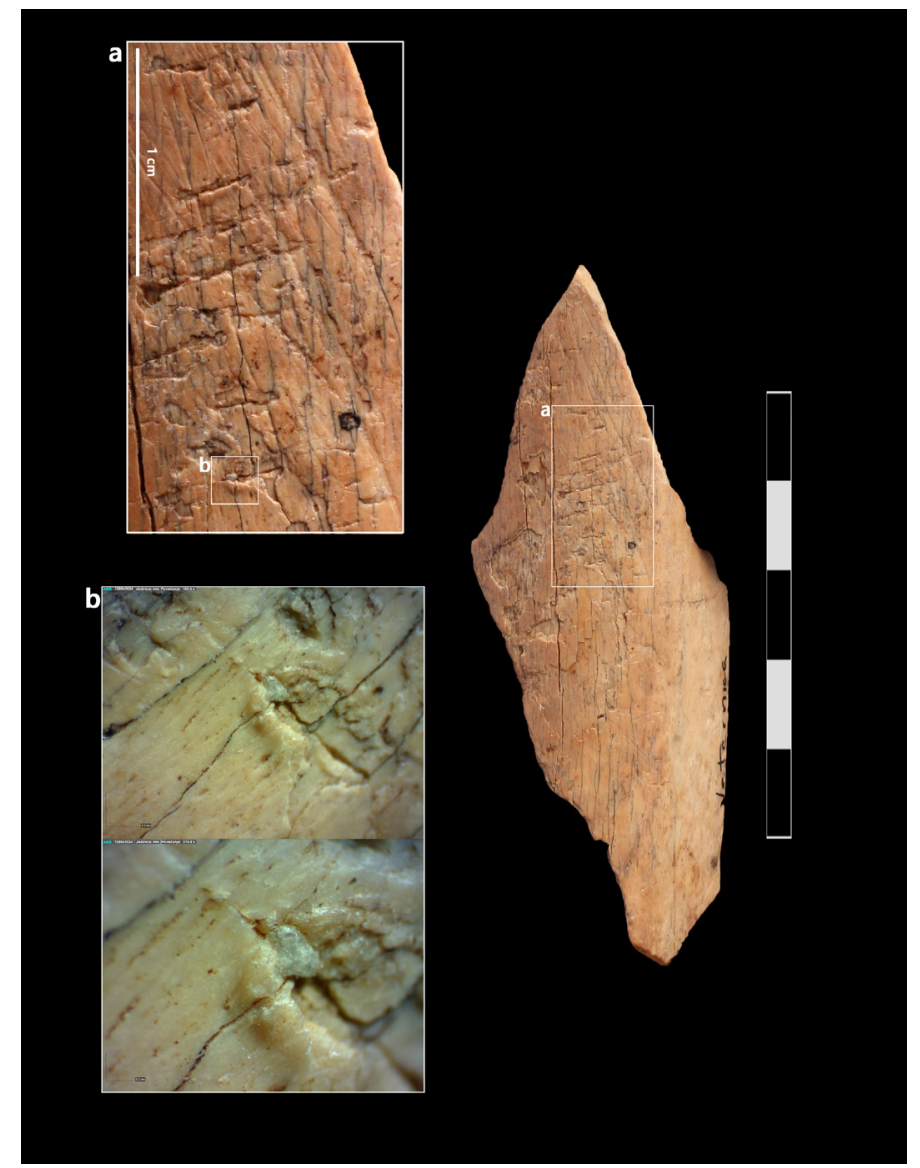

Figure 9. Retoucher VTR 17/R (Cervus elaphus, tibia) with a single use-area and scraping marks. a) Detail of the use area. b) Detail of a possible quartz chip imbedded in a linear mark. Scale $=5 \mathrm{~cm}$ (Photographed and edited by M. Banda).

subsistence strategies, given that a similar faunal spectrum is present in both site contexts. Thus, it seems that certain societal practices and choices played a much more crucial role. To that one might add that lithic technology could be a driving factor in retoucher variability, in that the shapes and sizes of lithic supports in need of retouch determine the required morphological parameters of bone blanks and that the desired shape and extent of retouch determines the use mode of retouchers and its intensity.

\section{Conclusion}

The study of bone retouchers in Veternica and Vindija expands our knowledge on this technology during the Middle Palaeolithic and Early Upper Palaeolithic in South-Central Europe. Significant differences between the sites in terms of size, morphometrical uniformity, faunal selection, preparation and length and intensity of use may point to a different degree of importance of the bone retoucher technology in the two chronologically different contexts. As only two sites are taken into consideration, whether this difference represents a diachronic and regional change requires further data and future discoveries. All in all, bone retoucher technology links subsistence strategies to stone tool technology and the character of the lithic industry probably influenced the requirements and practices related to the retouchers themselves. 
Despite our efforts, more can be done in the study of retouchers from Veternica and Vindija, and certain questions should in the future be addressed with the support of experimental studies and other methods.

\section{Acknowledgements and statements}

We would like to thank the director of the Institute for Quaternary Palaeontology and Geology, Jadranka Mauch Lenardić, for permitting us to study and publish the material. Mateo Petrović we sincerely thank for his help with photographing the artefacts.

Data availability statement. The authors confirm that the data supporting the findings of this study are available within the article.

Disclosure statement. No potential conflict of interest was reported by the authors.

Funding statement. The authors received no financial support for the research and the publication of this article.

\section{References}

Abrams G., Bello S.M., Di Modica K., Pirson S., \& Bonjean D. (2014). When Neanderthals used cave bear (Ursus spelaeus) remains: Bone retouchers from unit 5 of Scladina Cave (Belgium). Quaternary International, 326-327, 274-287. https://doi.org/10.1016/j. quaint.2013.10.022

Abrams G. (2018). Palaeolithic bone retouchers from Belgium: A preliminary overview of the recent research through historic and recently excavated bone collections. In J.M. Hutson, A. García-Moreno, E.S. Noack, E. Turner, A. Villaluenga, S. Gaudzinski-Windheuser (Eds.), The Origins of Bone Tool Technologies. "Retouching the Palaeolithic: Becoming Human and the Origins of Bone Tool Technology" Conference at Schloss Herrenhausen in Hannover, Germany, 21.-23. October 2015 (pp. 197-213). Römisch-Germanisches Zentralmuseum, Leibniz-Forschungsinstitut für Archäologie.

Ahern J.C.M., Karavanić I., Paunović M., Janković I., \& Smith F.H. (2004). New discoveries and interpretations of hominid fossils and artifacts from Vindija Cave, Croatia. Journal of Human Evolution, 46, 25-65. https://doi.org/10.1016/j.jhevol.2003.09.010

Armand D., \& Delagnes A. (1998). Les retouchoirs en os d'Artenac (couche 6c): perspectives archéozoologiques, taphonomiques et expérimentales. In J.-P. Brugal, L. Meignen, \& M. Patou-Mathis (Eds.), Économie Préhistorique: Les Comportements de Subsistance au Paléolithique. XVIIIe Rencontre Internationale d'Archéologie et d'Histoire d'Antibes (pp. 205-214). Éditions APDCA.

Auguste P. (2002). Fiche éclats diaphysaires du Paléolithique moyen: Biache-Saint-Vaast (Pas-de-Calais) et Kulna (Moravie, République tchèque). In M. Patou-Mathis (Ed.), Retouchoirs, compresseurs, percuteurs...Os à impressions et éraillures (pp. 39-57). Société préhistorique française.

Banda M., \& Karavanić I. (2019). Mustjerska industrija špilje Veternice / The Mousterian industry of Veternica Cave. Prilozi instituta za arheologiju u Zagrebu, 36, 5-40. https://doi.org/10.33254/piaz.36.1

Barandiarán I. (1987). Manipulación y uso de restos óseos. In P. Utrilla, J. Vílchez, L. Montes, I. Barandiarán, J. Altuna, E. Gil, P. López (Eds.),
La cueva de Peńa Miel. Nieva de Cameros, La Rioja. Excavaciones Arqueológicas en Espańa 154 (pp. 87-101). Ministerio de Cultura.

Bello S.M., Parfitt S.A., De Groote I., \& Kennaway G. (2013). Investigating experimental knapping damage on an antler hammer: a pilot-study using high-resolution imaging and analytical techniques. Journal of Archaeological Science, 40, 4528-4537. https://doi. org/10.1016/j.jas.2013.07.016

Binford L.R. (1981). Bones: Ancient men and modern myths. Academic Press.

Blasco R., Rosell J., Cuartero F., Peris J. F., Gopher A., \& Barkai R. (2013). Using bones to shape stones: MIS 9 bone retouchers at both edges of the Mediterranean Sea. PLoS One, 8(10), e76780. https://doi. org/10.1371/journal.pone.0076780

Blaser F., Kurtanjek D., \& Paunović M. (2002). L’industrie du site néandertalien de la grotte de Vindija (Croatie): une révision des matieres premieres lithiques. L'Anthropologie, 106(3), 387-398. https:// doi.org/10.1016/S0003-5521(02)01118-4

Brajković D. (2005). Korelacija tafodema skupine ungulata iz gornjopleistocenskih sedimenata špilja Vindija, Velika pećina i Veternica u sjeverozapadnoj Hrvatskoj. [Unpublished Ph.D. Dissertation]. Sveučilište u Zagrebu.

Broglio A., \& Kozłowski J. (1987). Il Paleolitico: Uomo, ambiente e culture. Jaca Book.

Bruner K.M. (2009). Testing Stratigraphic Integrity of Upper and Middle Paleolithic Deposits in Vindija Cave (Croatia): a Chipped Stone Refitting Analysis. [Unpublished Master's Thesis]. University of Kansas.

Campmas E. (2012). Caractérisation de l'occupation des sites de la région de Témara (Maroc) au Pléistocène supérieur et nouvelles données sur la subsistance des hommes du Paléolithique moyen d'Afrique du Nord : Exemples des approches taphonomiques et archéozoologiques menées sur les faunes d'El Harhoura 2 et d'El Mnasra. [Unpublished Ph.D. Dissertation]. Université Bordeaux 1.

Cartmill M., \& Smith F.H. (2009). The Human Lineage. Wiley-Blackwell. Castel J.C., Chauvière F.X., \& Madelaine S. (2003). Sur os et sur dents: les "retouchoirs" aurignaciens de la Ferassie (Savignac-de-Miremont, Dordogne). Paleo, 15, 29-50. https://doi.org/10.4000/ paleo.1212

Castel J.C. (2004). L'influence des canidés sur la formation des ensembles archéologiques: Caractérisation des destruction dues au loup. Revue de Paléobiologie, 23(2), 675-693.

Chase P.G. (1990). Tool-making tools and Middle Paleolithic behavior. Current Anthropology, 31, 443-447. https://doi.org/10.1086/203869

Conrad N.J., \& Bolus M. (2006). The Swabian Aurignacian and its place in European prehistory. In O. Bar-Yosef, \& J. Zilhão (Eds.), Towards a Definition of the Aurignacian. Proceedings of the Symposium held in Lisbon, Portugal, June 25-30, 2002. Trabalhos de Arqueologia 45 (pp. 211-239). Instituto Português de Arqueologia.

Costamagno S., Bourguignon L., Soulier M .C., Meignen L., Beauval,C., Rendu W., Mussini C., Mann A., \& Maureille B. (2018). Bone Retouchers and site function in the Quina Mousterian: the case of Les Pradelles (Marillac-le-France, France). In J. M. Hutson, A. García-Moreno, E. S. Noack, E. Turner, A. Villaluenga, S. Gaudzinski-Windheuser (Eds.), The Origins of Bone Tool Technologies. "Retouching the Palaeolithic: Becoming Human and the Origins of Bone Tool Technology" Conference at Schloss Herrenhausen in Hannover, Germany, 21.-23. October 2015 (pp. 165-195). Römisch-Germanisches Zentralmuseum, Leibniz-Forschungsinstitut für Archäologie.

Davidson I. (2018). Touching language origins again: how worked bone shaped our understanding. In J. M. Hutson, A. García-Moreno, E. S. Noack, E. Turner, A. Villaluenga, S. Gaudzinski-Windheuser (Eds.), 
The Origins of Bone Tool Technologies. "Retouching the Palaeolithic: Becoming Human and the Origins of Bone Tool Technology" Conference at Schloss Herrenhausen in Hannover, Germany, 21.-23. October 2015 (pp. 5-13). Römisch-Germanisches Zentralmuseum, LeibnizForschungsinstitut für Archäologie.

Daujeard C., Moncel M. H., Fiore I., Tagliacozzo A., Bindon P., \& Raynal J. P. (2014). Middle Paleolithic bone retouchers in Southeastern France: Variability and functionality. Quaternary International, 326-327, 492-518. https://doi.org/10.1016/j.quaint.2013.12.022

Daujeard C., Valensi P., Fiore I., Moigne A. M., Tagliacozzo A., Moncel M. H., Santagata C., Cauche D., \& Raynal J. P. (2018). A reappraisal of Lower to Middle Palaeolithic bone retouchers from Southeastern France (MIS 11 to 3). In J. M. Hutson, A. García-Moreno, E. S. Noack, E. Turner, A. Villaluenga, S. Gaudzinski-Windheuser (Eds.), The Origins of Bone Tool Technologies. "Retouching the Palaeolithic: Becoming Human and the Origins of Bone Tool Technology" Conference at Schloss Herrenhausen in Hannover, Germany, 21.-23. October 2015 (pp. 93-132). Römisch-Germanisches Zentralmuseum, Leibniz-Forschungsinstitut für Archäologie.

d'Errico F., \& Henshilwood C. S. (2007). Additional evidence for bone technology in the southern African Middle Stone Age. Journal of Human Evolution, 52, 142-163. https://doi.org/10.1016/j. jhevol.2006.08.003

Devièse, T., Karavanić, I., Comeskey, D., Kubiak, C., Korlević, P., Hajdinjak, M., Radović, S., Procopio, N., Buckley, M., Pääbo S., \& Higham, T. (2017). Direct dating of Neanderthal remains from the site of Vindija Cave and implications for the Middle to Upper Paleolithic transition. Proceedings of the National Academy of Sciences, 114(40), 10606-10611. https://doi.org/10.1073/pnas.1709235114

Doyon L., Li, Z., Li, H., \& d'Errico, F. (2018). Discovery of circa 115,000-year-old bone retouchers at Lingjing, Henan, China. PLoS ONE, 13(3), e0194318. https://doi.org/10.1371/journal. pone.0194318

Doyon L., Li, H., Li, Z., Wang, H., \& Zhao, Q. (2019). Further Evidence of Organic Soft Hammer Percussion and Pressure Retouch from Lingjing (Xuchang, Henan, China). Lithic Technology, 44(2), 100-117. https://doi.org/10.1080/01977261.2019.1589926

Fernández-Jalvo, Y., \& Andrews, P. (2016). Atlas of Taphonomic Identifications. Springer. https://doi.org/10.1007/978-94-017-7432-1

Giacobini, G., \& Patou-Mathis, M. (2002). Fiche rappels taphonomiques. In M. Patou-Mathis (Ed.), Retouchoirs, compresseurs, percuteurs...Os à impressions et éraillures (pp. 21-28). Société préhistorique française.

Griggo, C., Boëda, E., Bonilauri, S., Al Sakhel, H., Emery-Barbier, A., \& Courty, M. A. (2011). A Mousterian dromedary huntig camp: Level VI1aO at Umm el Tlel (El Kowm, Central Syria). In F. Bon, S. Costamagno, N. Valdeyron (Eds.), Hunting Camps in Prehistory: Current Archaeological Approaches. Proceedings of the International Symposium, May 13-15 2009 (pp. 103-129). University Toulouse II - Le Mirail.

Henri-Martin L. (1906). Maillets ou enclumes en os provenant de la couche moustérienne de la Quina (Charente). Bulletin de la Société préhistorique française, 3(4), 155-162. https://doi.org/10.3406/ bspf.1906.11456

Henshilwood C.S., d'Errico F., Marean C.W., Milo R.G., \& Yates R. (2001). An early bone tool industry from the Middle Stone Age at Blombos Cave, South Africa: implications for the origins of modern human behaviour, symbolism and language. Journal of Human Evolution, 41, 631-678. https://doi.org/10.1006/jhev.2001.0515

Hutson, J. M., Villaluenga, A., García-Moreno, A., Turner, E., \& Gaudzinski-Windheuser, S. (2018). On the use of metapodials as tools at
Schöningen 13II-4. In J. M. Hutson, A. García-Moreno, E. S. Noack, E. Turner, A. Villaluenga, S. Gaudzinski-Windheuser (Eds.), The Origins of Bone Tool Technologies. "Retouching the Palaeolithic: Becoming Human and the Origins of Bone Tool Technology" Conference at Schloss Herrenhausen in Hannover, Germany, 21.-23. October 2015 (pp. 53-91). Römisch-Germanisches Zentralmuseum, LeibnizForschungsinstitut für Archäologie.

Jéquier, C. A., Romandini, M., \& Peresani, M. (2012). Les retouchoirs en matières dures animales : une comparaison entre Moustérien final et Uluzzien. Comptes Rendus Palevol, 11, 283-292. https://doi. org/10.1016/j.crpv.2011.12.001

Jéquier, C. A., Livarghi, A., Romandini, M., \& Peresani, M. (2018). Same but different: 20,000 years of bone retouchers from Northern Italy. A diachronologic approach from Neanderthals to anatomically modern humans. In J. M. Hutson, A. García-Moreno, E. S. Noack, E. Turner, A. Villaluenga, S. Gaudzinski-Windheuser (Eds.), The Origins of Bone Tool Technologies. "Retouching the Palaeolithic: Becoming Human and the Origins of Bone Tool Technology" Conference at Schloss Herrenhausen in Hannover, Germany, 21.-23. October 2015 (pp. 269-285). Römisch-Germanisches Zentralmuseum, Leibniz-Forschungsinstitut für Archäologie.

Karavanić, I. (1995). Upper Paleolithic occupation levels and late-occurring Neandertal at Vindija Cave (Croatia) in the context of Central Europe and the Balkans. Journal of Anthropological Research, 51(1), 9-35. https://doi.org/10.1086/jar.51.1.3630370

Karavanić, I., \& Smith, F.H. (1998). The Middle/Upper Paleolithic interface and the relationship of Neanderthals and early modern humans in the Hrvatsko Zagorje, Croatia. Journal of Human Evolution, 34, 223-248. https://doi.org/10.1006/jhev.1997.0192

Karavanić, I., \& Šokec, T. (2003). The Middle Paleolithic Percussion or Pressure Flaking Tools? The comparison of experimental and archaeological material from Croatia. Prilozi instituta za arheologiju, 20, 5-14.

Karavanić, I., \& Patou-Mathis, M. (2009). Middle/Upper Paleolithic Interface in Vindija Cave (Croatia): New Results and Interpretations. I: M. Camps, P. R. Chauhan (Eds.), Sourcebook of Paleolithic Transitions: Methods, Theories, and Interpretations (pp. 397-405). Springer. https://doi.org/10.1007/978-0-387-76487-0_26

Karavanić, I., \& Smith, F. H. (2013). Alternative interpretations of the Middle/Upper Paleolithic interface at Vindija Cave (Northwestern Croatia) in the context of Central Europe and the Adriatic. Archaeology, Ethnology \& Anthropology of Eurasia, 41(4), 11-20. https://doi.org/10.1016/j.aeae.2014.07.003

Kolobova, K. A., Markin, S. V., \& Chabai V. P. (2016). Kostanye retushery v srednepaleoliticheskih kompleksah Chagyrskoj peshery / Bone retouchers in the Middle Paleolithic complexes of Chagyrskaya cave. Теория и практика археологических исследований, 16(4), 35-39. https://doi.org/10.14258/tpai(2016)4(16).-03

Kozłowski, J. K. (1992). The Balkans in the Middle and Upper Palaeolithic: the gate to Europe or a cul-de-sac? Proceedings of the Prehistoric Society, 58, 1-20. https://doi.org/10.1017/ S0079497X00004059

Kozłowski, J. K. (1996). Cultural context of the last Neanderthals and early Modern Humans in Central-Eastern Europe. In O. Bar-Yosef, L. L. Cavalli-Sforza, R. J. March, M. Piperno (Eds.), Proceedings of the XIII UISPP Congress, The Lower and the Middle Palaeolithic (pp. 205-218). Abaco

Kurtanjek, D., \& Marci, V. (1990). Petrografska istraživanja paleolitskih artefakata spilje Vindije. Rad Jugoslavenske akademije znanosti i umjetnosti, 449, 227-238. 
Leonardi, P. (1979). Una serie di ritoccatoi prevalentemente musteriani del Riparo Tagliente in Valpantena presso Verona. Preistoria Alpina, 15, 7-15.

Leroy-Prost, C. (2002). Fiche canines de carnivores. In M. Patou-Mathis (Ed.), Retouchoirs, compresseurs, percuteurs...Os à impressions et éraillures. Paris: Société préhistorique française, 99-104.

Lyman, R. L. (1994). Vertebrate Taphonomy. Cambridge: Cambridge University Press. https://doi.org/10.1017/CBO9781139878302

Malerba, G., Giacobini, G. (2002). Fiche eclats diaphysaires avec marques transversales d'utilisation. In: Patou-Mathis M. (ed.), Retouchoirs, compresseurs, percuteurs...Os à impressions et éraillures (pp. 29-37). Société préhistorique française.

Malez, M. (1958). Neki noviji rezultati paleontološkog istraživanja pećine Veternice, Palaeontologia Jugoslavica 1. Jugoslavenska akademija znanosti i umjetnosti.

Malez, M. (1963). Kvartarna fauna pećine Veternice u Medvednici. Palaeontologia Jugoslavica 5. Jugoslavenska akademija znanosti i umjetnosti.

Malez, M. (1965). Pećina Veternica u Medvednici. 1. Opći speleološki pregled. 2. Stratigrafija kvartarnih taložina. In: M. Tajder, \& M. Salopek (Eds.), Acta geologica V. Prirodoslovna istraživanja Jugoslavenske akademije znanosti $i$ umjetnosti 35. (pp. 175-238). Jugoslavenska akademija znanosti i umjetnosti.

Malez, M. (1967). Paleolitska nalazišta Hrvatske. Arheološki vestnik, 18, 255-290.

Malez, M. (1981). Paleolitik na području Zagreba. In: Rapanić Ž. (ed.), Arheološka istraživanja u Zagrebu i njegovoj okolici. Izdanja Hrvatskog arheološkog društva 6 (pp. 65-108). Hrvatsko arheološko društvo.

Malez, M., \& Rukavina, D. (1979). Položaj naslaga spilje Vindije u sustavu članjenja kvartara šireg područja Alpa. Rad Jugoslavenske akademije znanosti $i$ umjetnosti, 383, 187-218.

Malez, M., Smith, F. H., Radovčić, J., Rukavina, D. (1980). Upper Pleistocene hominids from Vindija, Croatia, Yugoslavia. Current Anthropology, 21(3), 365-367. https://doi.org/10.1086/202463

Mallye, J.-B., Thiébaut, C., Mourre, V., Costamagno, S., Claud, É., \& Weisbecker, P. (2012). The Mousterian bone retouchers of Noisetier Cave: experimentation and identification of marks. Journal of Archaeological Science, 39, 1131-1142. https://doi.org/10.1016/j. jas.2011.12.018

Mateo-Lomba, P., Rivals, F., Blasco, R., Rosell, J. (2019). The use of bones as retouchers at Unit III of Teixoneres Cave (MIS 3; Moià, Barcelona, Spain). Journal of Archaeological Science: Reports, 27, Article 101980. https://doi.org/10.1016/j.jasrep.2019.101980

Mihailović, D. (2014). Paleolit na centralnom Balkanu: kulturne promene i populaciona kretanja. Srpsko arheološko društvo.

Miracle, P. T. (1991). Carnivore Dens or Carnivore Hunts? A Review of Upper Pleistocene Mammalian Assemblages in Croatia and Slovenia. Rad Hrvatske akademije znanosti i umjetnosti, 458, 193-219.

Miracle, P. T. (2007). The Krapina Paleolithic site: Zooarchaeology, taphonomy, and catalog of the faunal remains. Hrvatski prirodoslovni muzej/Croatian Natural History Museum.

Miracle, P. T., Brajković, D. (1992). Revision of the ungulate fauna and Upper Pleistocene stratigraphy of Veternica Cave (Zagreb, Croatia). Geologia Croatica, 45(1), 1-14.

Miracle, P. T., \& Brajković, D. (2010). The palaeoecological significance of the Pleistocene mammalian fauna from Veternica Cave, Croatia. Revision of the lagomorpha, canidae, mustelidae and felidae. Geologia Croatica, 63(2), 207-224. https://doi.org/10.4154/ gc.2010.18
Miracle, P., \& Pugsley, L. (2006). Vertebrate Faunal Remains at Pupićina Cave. In: Miracle P., Forenbaher S. (eds.), Prehistoric Herders of Northern Istria: The Archaeology of Pupicina Cave, Vol. 1. Monografije i katalozi 14. (pp. 259-399). Arheološki muzej Istre.

Miracle, P. T., Mauch Lenardić, J., \& Brajković, D. (2010). Last Glacial Climates, "Refugia", and Faunal Change in Southeastern Europe: Mammalian Assemblages from Veternica, Velika pećina, and Vindija Caves (Croatia). Quaternary International, 212(2), 137-148. https://doi.org/10.1016/j.quaint.2009.06.003

Moigne, A. M., Valensi, P., Auguste, P., García-Solano, J., Tuffreau, A., Lamotte, A., Barroso, C., \& Moncel, M. H. (2016). Bone retouchers from Lower Palaeolithic sites: Terra Amata, Orgnac 3, Cagny l'Epinette and Cueva del Angel. Quaternary International, 409, 195212. https://doi.org/10.1016/j.quaint.2015.06.059

Montet-White, A. (1996). Le Paléolithique en ancienne Yougoslavie. Jérôme Millon.

Morin, E., Soulier, M. C. (2017). The Paleolithic Faunal Remains from Crvena Stijena. In R. Whallon (Ed.), Crvena stijena in Cultural and Ecological Context: Multidisciplinary Archaeological Research in Montenegro. (pp. 266-294). Montenegrian Academy of Science and Arts, National Museum of Montenegro.

Mozota, M. (2009). El utillaje óseo musteriense del nivel "D" de Axlor (Dima, Vizcaya): análisis de la cadena operativa. Trabjos de Prehistoria, 66(1), 27-46. https://doi.org/10.3989/tp.2009.09011

Mozota, M. (2013). An experimental programme for the collection and use of retouching tools made on diaphyseal bone splinters. EXARC Journal, 2013(2).

Mozota, M. (2015). Un análisis tecno-funcional de los retocadores óseos musterienses del norte de la Península Ibérica, y su aplicación al estudio de los grupos neandertales. Munibe Antropologia-Arkeologia, 66, 5-21. https://doi.org/10.21630/maa.2015.66.01

Mozota, M. (2018). Experimental programmes with retouchers: where do we stand and where do we go now? In J. M. Hutson, A. García-Moreno, E. S. Noack, E. Turner, A. Villaluenga, S. Gaudzinski-Windheuser (Eds.), The Origins of Bone Tool Technologies. "Retouching the Palaeolithic: Becoming Human and the Origins of Bone Tool Technology" Conference at Schloss Herrenhausen in Hannover, Germany, 21.-23. October 2015 (pp. 15-32). Römisch-Germanisches Zentralmuseum, Leibniz-Forschungsinstitut für Archäologie.

Mussini, C. (2011). Les restes humains moustériens des Pradelles (Marillac-le-Franc, Charente, France): étude morphométrique et réflexions sur un aspect comportemental des Néandertaliens. [Unpublished Ph.D. Dissertation]. Université de Bordeaux 1.

Neruda, P., Kaminská, L. (2013). Neanderthals at Bojnice in the context of Central Europe / Neandertálci z Bojnic v kontextu střední Evropy. Anthropos 36. Moravské zemské muzeum, Archeologický ústav SAV.

Neruda, P., \& Lázničková-Galetová, M. (2018). Retouchers from mammoth tusks in the Middle Palaeolithic: A case study from Kůlna cave layer 7a1 (Czech Republic). In J. M. Hutson, A. García-Moreno, E. S. Noack, E. Turner, A. Villaluenga, S. Gaudzinski-Windheuser (Eds.), The Origins of Bone Tool Technologies. "Retouching the Palaeolithic: Becoming Human and the Origins of Bone Tool Technology" Conference at Schloss Herrenhausen in Hannover, Germany, 21.-23. October 2015 (pp. 215-233). Römisch-Germanisches Zentralmuseum, Leibniz-Forschungsinstitut für Archäologie.

Neruda, P., Lázničková-Galetová M., Dreslerová G. (2011). Retušéry a kosti s rýhami z jeskyně Kůlny v Moravském krasu: interdisciplinární analýza tvrdých živočišných tkáni ze středopaleolitických horizontů. Anthropos 33. Moravské zemské muzeum. 
Patou-Mathis, M. (1997). Analyses taphonomique et palethno graphique du materiel osseux de Krapina (Croatie): novelles données sur la faune et les restes humains. Préhistoire Européenne, 10, 63-90.

Patou-Mathis, M., \& Schwab, C. (2002). Fiche générale. In M. PatouMathis (Ed.), Retouchoirs, compresseurs, percuteurs...Os à impressions et éraillures. (pp. 11-19). Société préhistorique française.

Patou-Mathis, M., Karavanić, I., \& Smith, F. H. (2018). The evidence from Vindija Cave (Croatia) reveals diversity of Neandertal behaviour in Europe. Quaternary International, 494, 314-326. https:// doi.org/10.1016/j.quaint.2018.06.023

Reitz, E. J., \& Wing, E. S. (1999). Zooarchaeology. Cambridge Manual in Archaeology. Cambridge University Press.

Roberts, M. B., \& Parfitt, S. A. (1999). Boxgrove: A Middle Pleistocene Hominid Site at Eartham Quarry, Boxgrove, West Sussex. Archaeological Report 17. English Heritage.

Romandini M., Terlato G., Nannini N., Tagliacozzo A., Benazzi S., \& Peresani M. (2018). Bears and humans, a Neanderthal tale. Reconstructing uncommon behaviors from zooarchaeological evidence in southern Europe. Journal of Archaeological Science, 90, 71-91. https://doi.org/10.1016/j.jas.2017.12.004

Rosell, J., Blasco, R., Campeny, G., Díez, J. C., Alcalde, R. A., Menéndez, L., Arsuaga, J. L., Bermúdez de Castro, J. M., \& Carbonell, E. (2011). Bone as a technological raw material at the Gran Dolina site (Sierra de Atapuerca, Burgos, Spain). Journal of Human Evolution, 61, 125-131. https://doi.org/10.1016/j.jhevol.2011.02.001

Rosell, J., Blasco, R., Fernández Peris, J., Carbonell, E., Barkai, R., \& Gopher, A. (2015). Recycling bones in the Middle Pleistocene: some reflections from Gran Dolina TD10-1 (Spain), Bolomor Cave (Spain) and Qesem Cave (Israel). Quaternary International, 361, 297-312. https://doi.org/10.1016/j.quaint.2014.08.009

Rosell, J., Blasco, R., Martin-Lerma, I., Barkai, R., \& Gopher, A. (2018). When discarded bones became important: new bone retouchers from the lower sequence of Qesem Cave, Israel (ca. 300-420 ka). In J. M. Hutson, A. García-Moreno, E. S. Noack, E. Turner, A. Villaluenga, S. Gaudzinski-Windheuser (Eds.), The Origins of Bone Tool Technologies. "Retouching the Palaeolithic: Becoming Human and the Origins of Bone Tool Technology" Conference at Schloss Herrenhausen in Hannover, Germany, 21.-23. October 2015 (pp. 33-51). RömischGermanisches Zentralmuseum, Leibniz-Forschungsinstitut für Archäologie.

Rougier, H., Crevecoeur, I., Beauva,l C., Posth, C., Flas, D., Wißing, C., Furtwängler, A., Germonpré, M, Gómez-Olivencia, A., Sema,l P., van der Plicht, J., Bocherens, H., \& Krause, J. (2016). Neandertal cannibalism and Neandertal bones used as tools in Nothern Europe. Scientific Reports, 6, Article 29005. https://doi.org/10.1038/ srep29005

Schwab, C. (2002). Fiche éclats diaphysaires du Paléolithique moyen et supérieur: la grotte d'Isturitz (Pyrénées-Atlantique). In M. Patou-Mathis (Ed.), Retouchoirs, compresseurs, percuteurs...Os à impressions et éraillures (pp. 59-73). Société préhistorique française.

Sévêque, N., Auguste, P. (2018). From west to east: Lower and Middle Palaeolithic bone retouchers in northern France. In: In J. M. Hutson, A. García-Moreno, E. S. Noack, E. Turner, A. Villaluenga, S. Gaudzinski-Windheuser (Eds.), The Origins of Bone Tool Technologies. "Retouching the Palaeolithic: Becoming Human and the Origins of Bone Tool Technology" Conference at Schloss Herrenhausen in Hannover, Germany, 21.-23. October 2015 (pp. 133-164). RömischGermanisches Zentralmuseum, Leibniz-Forschungsinstitut für Archäologie.
Smith, F. H., Boyd, C. D., \& Malez, M. (1985). Additional upper Pleistocene human remains from Vindija cave, Croatia, Yugoslavia. American Journal of Physical Anthropology, 68(3), 375-388. https:// doi.org/10.1002/ajpa.1330680308

Smith, G. M. (2010). A contextual approach to the study of faunal assemblages from Lower and Middle Palaeolithic sites in the UK. [Unpublished PhD Dissertation]. University College London.

Smith, G. M. (2013). Taphonomic resolution and hominin subsistence behaviour in the Lower Palaeolithic: differing data scales and interpretive frameworks at Boxgrove and Swanscombe (UK). Journal of Archaeological Science, 40, 3754-3767. https://doi.org/10.1016/j. jas.2013.05.002

Soulier, M. C. (2014). L'exploitation alimentaire et technique du gibier au début du Paléolithique supérieur aux Abeilles (Haute-Garonne, France). Paleo, 25, 287-307. https://doi.org/10.4000/paleo.2829

Tartar, E. (2012). Réflexion autour de la fonction des retouchoirs en os de l'Aurignacien ancien. Bulletin de la Société préhistorique française, 109(1), 69-83. https://doi.org/10.3406/bspf.2012.14143

Taute, W. (1965). Retoucheure aus Knochen, Zahnbein und Stein vom Mittelpaläolithikum bis zum Neolithikum. Fundberichte aus Schwaben, 17, 76-102.

Tourloukis, V., Thompson, N., Panagopoulou, E., Giusti, D., Konidaris, G. E., Karkana,s P., \& Harvati, K. (2018). Lithic artifacts and bone tools from the Lower Palaeolithic site Marathousa 1, Megalopolis, Greece: Preliminary results. Quaternary International, 497, 47-64. https://doi.org/10.1016/j.quaint.2018.05.043

Turk, I., \& Dirjec ,J. (1989). Apnarjeva jama - Novo moustériensko najdišče: Poročilo o sondiranju 1987/1988. Celjski zbornik, 25, 7-19.

Valensi, P., \& Psathi, E. (2004). Faunal Exploitation during the Middle Palaeolithic in South-eastern France and North-western Italy. International Journal of Osteoarchaeology, 14, 256-272. https://doi. org/10.1002/oa.760

van Kolfschoten, T., Parfitt, S. A., Serangeli, J., \& Bello, S. M. (2015). Lower Paleolithic bone tools from the 'Spear Horizon' at Schöningen (Germany). Journal of Human Evolution, 89, 226-263. https:// doi.org/10.1016/j.jhevol.2015.09.012

Verna, C., d'Errico, F. (2011). The earliest evidence for the use of human bone as a tool. Journal of Human Evolution, 60, 145-157. https:// doi.org/10.1016/j.jhevol.2010.07.027

Veselsky, A. P. (2008). Kabazi V: Bone and Stone Tools Used in Flint Knapping. In V. Chabai, J. Richter, T. Uthmeier, Kabazi V: Interstratification of Micoquian \& Levallois-Mousterian Camp Sites. Palaeolithic Sites of Crimea 3, Part 2. (pp. 427-454). National Academy of Sciences of Ukraine - Institute of Archaeology Crimean Branch, University of Cologne - Institute of Prehistoric Archaeology.

Villa, P., Mahieu, E. (1991). Breakage patterns of human long bones. Journal of Human Evolution, 21(1), 27-48. https://doi. org/10.1016/0047-2484(91)90034-S

Vuković, S. (1950). Paleolitska kamena industrija spilje Vindije. Historijski zbornik, 3, 241-256.

Wolpoff, M. H. (1999). Paleoanthropology (2nd edition). McGraw-Hill. Wolpoff, M. H., Smith, F. H., Malez, M., Radovčić, J., \& Rukavina, D. (1981). Upper Pleistocene human remains from Vindija cave, Croatia, Yugoslavia. American Journal of Physical Anthropology, 54(4), 499-545. https://doi.org/10.1002/ajpa.1330540407

Zilhão, J. (2009). Szeletian, Not Aurignacian: A Review of the Chronology and Cultural Associations of the Vindija G1 Neandertals. In M. Camps, P. R. Chauhan (Eds.), Sourcebook of Paleolithic Transitions: Methods, Theories, and Interpretations (pp. 407-426). Springer. https://doi.org/10.1007/978-0-387-76487-0_27 